OPEN ACCESS

Edited by:

Yosuke Aoki,

The University of Tokyo, Japan

Reviewed by:

Khaled Hessami, International Institute of Earthquake Engineering and Seismology, Iran Rou-Fei Chen,

National Taipei University of Technology, Taiwan

*Correspondence: Yu-Chang Chan yuchang@earth.sinica.edu.tw

Specialty section:

This article was submitted to Structural Geology and Tectonics, a section of the journal

Frontiers in Earth Science

Received: 15 July 2021 Accepted: 23 December 2021 Published: 21 January 2022

Citation:

Dinh T-H, Chan Y-C and Chen C-T

(2022) Extensional Tectonics and Basement Uplift of the Fansipan and

Tule Mountain Ranges in Northern Vietnam.

Front. Earth Sci. 9:741670. doi: 10.3389/feart.2021.741670

\section{Extensional Tectonics and Basement Uplift of the Fansipan and Tule Mountain Ranges in Northern Vietnam}

\author{
Thi-Hue Dinh ${ }^{1,2,3}$, Yu-Chang Chan ${ }^{1,2 *}$ and Chih-Tung Chen ${ }^{3}$ \\ ${ }^{1}$ Taiwan International Graduate Program (TIGP) - Earth System Sciences Program, Academia Sinica and National Central \\ University, Taipei, Taiwan, ${ }^{2}$ Institute of Earth Sciences, Academia Sinica, Taipei, Taiwan, ${ }^{3}$ Department of Earth Sciences, National \\ Central University, Taoyuan, Taiwan
}

The Fansipan and Tule mountain ranges, northern Vietnam, are regions with high elevations and are adjacent to the Red River Fault, which is an important structure that is related to the India-Eurasia collision. How mountain elevations are maintained today under a humid subtropical climate is important for improving the knowledge of the tectonic deformations in northern Vietnam and may have broader implications for the crustal dynamics of circum-Tibetan regions. We therefore utilized observations from field and digital elevation model (DEM) data and geomorphic analyses to constrain the active fault systems that have likely contributed to the uplift of mountain ranges. Our observations from DEM and field data indicate potential active normal and strike-slip faults such as the Phong Tho-Nam Pia Fault, Tule Fault, and Nghia Lo Fault. In addition to these observations, the results from geomorphic indices, which include both the stream-length gradient index (SL) and normalized steepness index $\left(\mathrm{k}_{\mathrm{sn}}\right)$, present high values for the footwalls of the inferred normal faults and low values for the hanging walls. Most of the identified knickpoints are related to the locations of mapped faults. Correlations of these data indicate that recent movements of the Fansipan and Tule mountain ranges are dominated by strike-slip and normal faulting under a NE-SW minimum extensional regime. We therefore propose that extensional tectonics associated with isostatic rebound likely plays a role in maintaining mountain elevations over long periods despite the continuous weathering and erosion present in monsoon-affected areas.

Keywords: stream-length gradient index, normalized steepness index (ksn), Fansipan and Tule mountain ranges, mountain uplift, isostatic rebound

\section{INTRODUCTION}

Over the last few decades, there has been increasing interest in how the Earth's crust deforms on the Tibetan Plateau and its surrounding regions as a result of the collision between the Indian and Eurasian plates (e.g., Burchfiel, 2004; Kirby and Ouimet, 2011; Molnar and Tapponnier, 1975; Shen et al., 2005; Tapponnier et al., 1982). Many studies have been carried out in mountainous areas within and surrounding major strike-slip faults, which are some of the most important structures related to the India-Eurasia collision (e.g., Schoenbohm et al., 2004; Wang et al., 2016, 2017). Most of these studies focused on analyzing the tectonic deformations in the central and eastern Tibetan Plateau to the Chinese Yunnan regions. There have been few studies in northern Vietnam despite this area being one of the key regions for understanding crustal deformation related to this collisional event, 
where the well-known Red River Fault (RRF), which is an important tectonic structure formed by the collision, cuts though the region (Tapponnier et al., 1990). In northern Vietnam, the abrupt high elevations of the Fansipan and Tule mountain ranges, which comprise mountain peaks that are more than $3,000 \mathrm{~m}$ above sea level, are present adjacent to the RRF, which is a strike-slip dominated fault. How such high elevations formed and were maintained under a humid subtropical monsoon climate is central to understanding the tectonic deformation in this area and may have implications for crustal dynamics in the circum-Tibetan region.

The elevations of mountain ranges are controlled by three main processes: tectonic forces, climate-controlled erosion and isostasy (Wang, 2020). Tectonic forces either push mountains up against gravity or prevent mountains from falling under their own weight. Climate-controlled erosion is the process of removing material and limits mountain heights. Isostasy maintains a balance between mountains and the viscous fluid of the mantle. Isostasy acts in response to the other two processes; thus, to explain how the elevations of mountains are maintained, it is necessary to understand the tectonic activities and erosional processes present in the study area. In northern Vietnam, the climate is subtropical monsoon, which is characterized by relatively high temperatures and humidity. Erosion in this region is intense and effectively removes materials from mountain ranges, as is proven by the thick soil layers with thicknesses up to a few meters. Under the intense impact of erosion, tectonic activities have a dominant role in maintaining the high elevations of mountain ranges. The mountain ranges were likely thickened in the subsurface with basal accretion of materials as shown in the case studies of Byrne et al. (2011) and Chen et al. (2018, 2019). At the same time, extensional mechanism may also accompany exhumation of mountains as indicated in the case studies of Crespi et al. (1996) and Stern et al. (2005). Therefore, in this study, we attempt to provide new data on the tectonic activities in the Fansipan and Tule mountain ranges to address the question of the driving mechanism that maintains the high elevations of these mountain ranges.

With the availability of digital elevation model (DEM) data, tectonic geomorphology studies have provided more insights for determining surface deformations and locating tectonic movements in active regions, especially in regions that are not easily accessible to mountainous areas (e.g., Kirby et al., 2000; Chen et al., 2015; Giletycz et al., 2015; Gaidzik and RamírezHerrera, 2017). DEM data are considered to be a powerful tool for visualizing the shapes of land surfaces and for quickly identifying geomorphic features, such as surface ruptures or offsets of rivers. As technological advances have dramatically improved, ALOS PALSAR $12.5-\mathrm{m}$ and ASTER $30-\mathrm{m}$ are the most recent freely available high-resolution DEM data in the world. Although applying these data to explore surface deformations and fault systems is widely used in active regions, this methodology is still new for studying tectonic deformations in Vietnam. This study used the DEM data from ASTER 30-m and ALOS PALSAR 12.5-m, which are the most recent high-resolution datasets available for northern Vietnam. The ASTER 30-m DEM is developed from stereo-pair images obtained by the Terra satellites that were launched to the space in December 1999. The ALOS PALSAR 12.5-m DEM is produced by the Advanced Land Observing Satellite launched in 2005. By using the DEM data from ASTER 30-m and ALOS PALSAR, we attempt to visualize the land surface and detect possible active movements in the Fansipan and Tule mountain ranges. To extract tectonic signals from topography, we analyzed geomorphic indices, including the stream-length gradient index (SL) and normalized steepness index $\left(\mathrm{k}_{\mathrm{sn}}\right)$, which are useful to investigate and explore the spatial distributions of tectonic activity in active areas (e.g., Font et al., 2010; Di Naccio et al., 2013; Chen et al., 2015; Gaidzik and Ramírez-Herrera, 2017). Combining the geological maps, Google Earth images, DEM data and field observations, we attempt to provide new data on the tectonic activities in the Fansipan and Tule mountain ranges to better constrain how mountain heights are maintained today, which may have broader implications for tectonic deformations in and surrounding the Tibetan Plateau.

\section{GEOLOGICAL BACKGROUND}

There are two main tectonic events that influenced the structural deformations in northern Vietnam (Figure 1). The first is the Indosinian Orogeny event that is related to the closure of the Paleo-Tethys Ocean, which was followed by the collision of the South China and Indochina plates during Permian-Triassic Time. Its boundary is defined in the Song Ma Zone (SMZ), where eclogite-bearing ophiolites are documented (Zhang et al., 2013). The second event is related to the southeast extrusion of the Indochina plate along the Ailao Shan-Red River shear zone (ASRRSZ) as a result of the India-Eurasia collision in Cenozoic time. The Red River Fault (RRF) is located on the flank of the AS-RRSZ and is an active strike-slip fault that is associated with recent crustal deformations that were affected by the India-Eurasia collision. In this study, the RRF and AS-RRSZ are separated into two different structures. The RRF exhibits active right-lateral movement (e.g., Allen et al., 1984; Schoenbohm et al., 2004), while the AS-RRSZ is an older structure that is characterized by left-lateral ductile shearing movement that occurred in the Oligocene-Miocene (e.g., Schärer et al., 1990; Tapponnier et al., 1990; Leloup et al., 2001). Numerous studies have addressed the influence of these two tectonic events on the tectonic deformations in northern Vietnam (e.g., Leloup et al., 1995; Chung et al., 1997; Leloup et al., 2001; Searle et al., 2010; Faure et al., 2014; Yeh et al., 2014). However, most of them focused only on the deformations at tectonic boundaries such as the SMZ, AS-RRSZ, and RRF, which have left a knowledge vacuum regarding the transition zones among them. The Fansipan and Tule mountain ranges are located between the RRF to the northeast and SMZ to the southwest (Figure 2, Figure 3) and may serve as an important area to bridge the gap in the structural evolution of the transition zones of these tectonic boundaries.

The Fansipan and Tule mountain ranges are approximately $30-50 \mathrm{~km}$ wide and $200 \mathrm{~km}$ long NW-trending topographically high regions with a highest elevation of $3,143 \mathrm{~m}$ above sea level. 


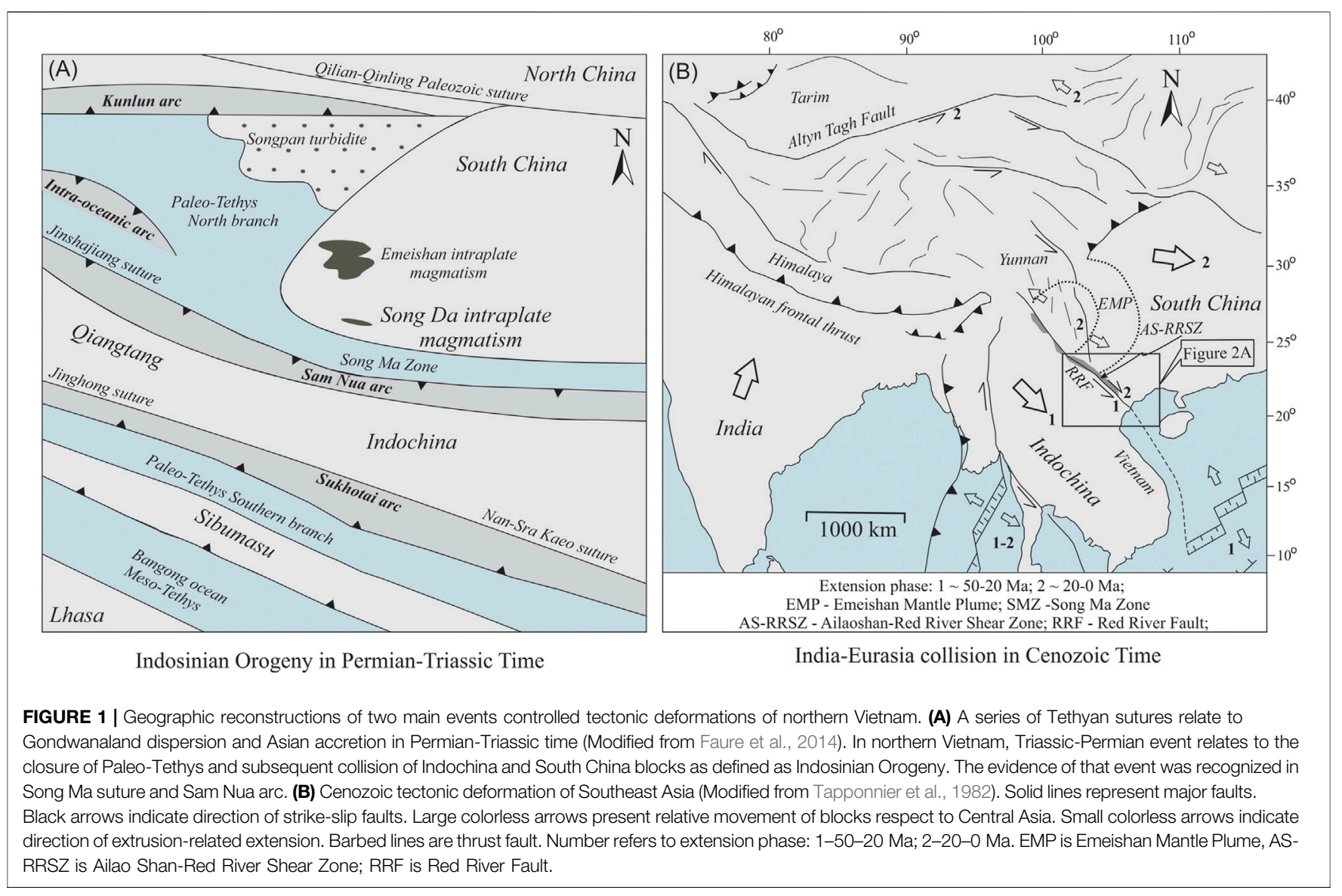

The Fansipan mountain range mainly consists of intrusive igneous rocks. The Permian-Triassic rocks in this mountain range are predominantly igneous rocks, but the ages of all igneous rocks present a range from Neoproterozoic to Cenozoic (Lan et al., 2001; Nam, 2001; Tran et al., 2015; Usuki et al., 2015). In contrast to the Fansipan mountain range, the Tule mountain range consists mainly of extrusive igneous rocks with Permian-Triassic ages (Shellnutt et al., 2020). Petrogenesis studies (Tran et al., 2015; Usuki et al., 2015) have indicated that the Permian-Triassic igneous rocks, including both the intrusive and extrusive rocks in the Fansipan and Tule mountain ranges, have a genetic relationship with rocks in the Emeishan Mantle Plume (EMP) in China. It is suggested that the displacement of the Fansipan and Tule blocks from the original location (China) to the current position (northern Vietnam) is due to shearing of the AS-RRSZ (Tran et al., 2015). The Fansipan and Tule mountain ranges are now known as a region with the highest elevations and thickest crust in northern Vietnam with a crustal thickness of approximately $40 \mathrm{~km}$ beneath these mountain ranges (Nguyen et al., 2013), but the source of crustal thickening remains unclear. Based on the literature, there are several explanations for the source of crustal thickening in these mountain ranges. One is that the crust in these mountain ranges thickened during the Indosinian episode and was related to the collision between the Indochina and South China plates (Carter and Clift, 2008).
The second is that the great crustal thickness accumulated as a result of magmatic activities related to mantle plumes (Tran et al., 2015). This is possible because the major rock type in these mountain ranges is the Permian-Triassic igneous rocks, and their origin is interpreted as being from a mantle plume associated with the EMP (Shellnutt et al., 2020; Tran et al., 2015). The other possibility is that the high elevations and thickened crust of the Fansipan and Tule mountain ranges formed as a result of crustal deformations related to the India-Eurasia collision (Leloup et al., 2001). This may have occurred because these mountain ranges are spatially associated with the Himalayan syntaxis through the RRF, which is one of the largest strike-slip faults that resulted from the India-Eurasia collision. Although the onset of crustal thickening that may have caused surface uplift in the Fansipan and Tule mountain ranges is uncertain, when considering the present high elevations of the Fansipan and Tule mountain ranges under humid subtropical monsoon climates, it is suspected that uplift of these mountain ranges has continued to this day. The discussion concerning about the role of erosion and tectonics on the mountain range have been mentioned in many published research works (Hooke, 2003; Clark et al., 2004; Burbank and Anderson, 2011; Wang, 2020). The erosion reduces the high elevation of the mountain by removing crust material. To maintain high elevations of the mountains for such a long time under erosional processes, the tectonics is the dominant factor driven uplift of the mountain range. Therefore, a detailed 


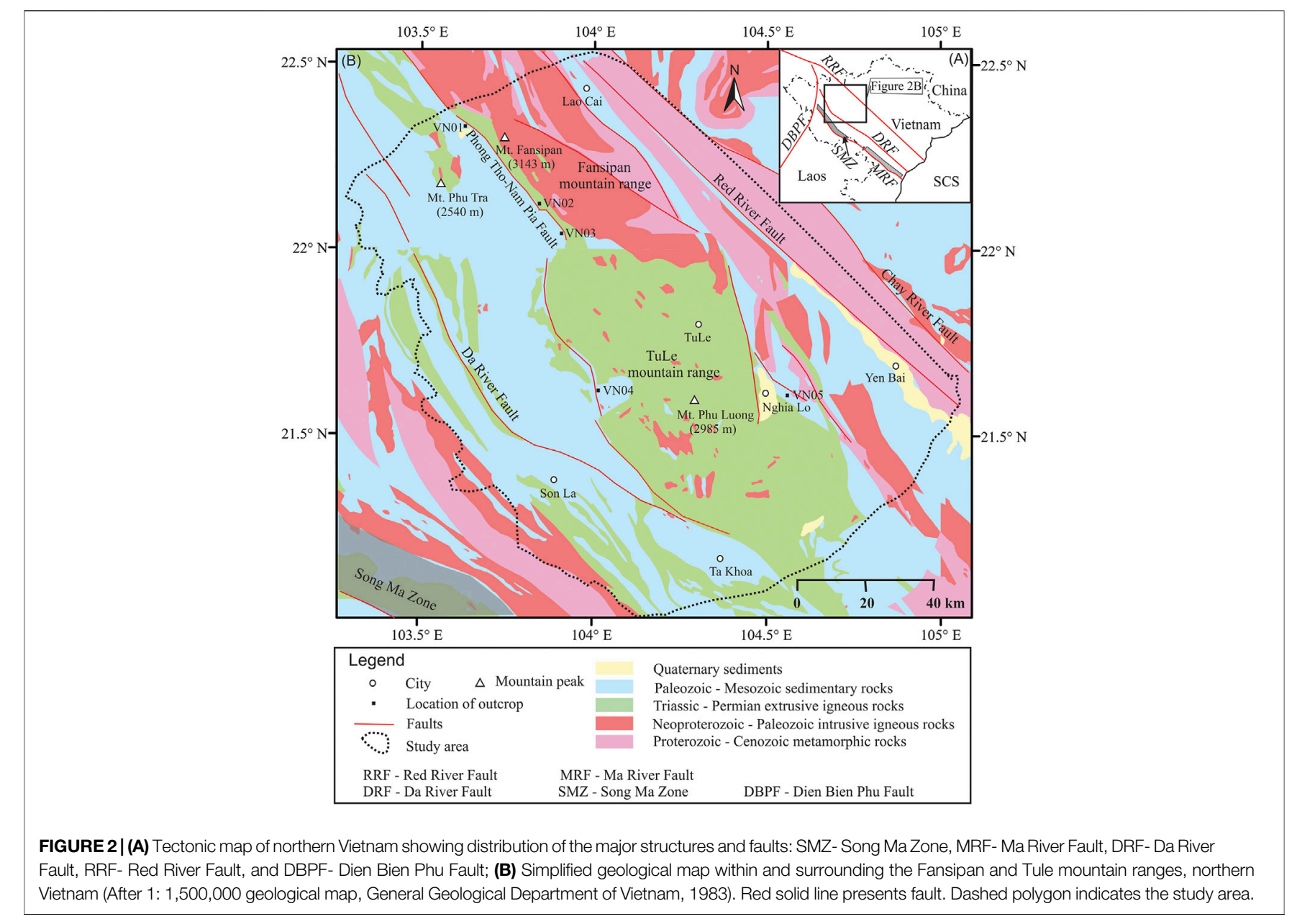

investigation of active movements in the Fansipan and Tule mountain ranges is necessary to understand the tectonic mechanism that maintains mountain elevations under intensive erosional processes. In this study, which is based on our previous work in the Fansipan mountain range (Dinh et al., 2020), we analyzed geomorphic features using high-resolution DEM data to provide constraints on the active movements in the Fansipan and Tule mountain ranges and to further understand the mountain building processes not only in Vietnam but also throughout the world.

\section{METHODS}

In this study, the ALOS PALSAR 12.5-m and ASTER 30-m DEMs were utilized to detect topographic features and surface lineaments. To identify whether the topographic features and surface lineaments detected are faults, we also compared them with the previous mapping of faults shown in geological maps and double-checked them from field data and high-resolution Google Earth images. Longitudinal river profiles were also constructed by using the DEMs. To obtain the tectonic deformation signals from the landscape, fifteen longitudinal river profiles were constructed. The names and locations of the analyzed rivers are shown in Figure 10. The procedures used to extract river profiles from DEM data are described in Dinh et al. (2020) and briefly below. A drainage system with flow direction and flow accumulation is constructed on a DEM, and data omissions and anomalies are removed. A stream network can then be delineated by setting the threshold value for flow accumulation $\left(105 \mathrm{~m}^{2}\right.$ for this work). Once the stream networks have been obtained, the river profiles can be extracted for stream-length gradient index (SL) and normalized steepness index $\left(\mathrm{k}_{\mathrm{sn}}\right)$ analyses (Figure 4).

The SL index was developed to reflect stream power in the pioneering study of Hack (1973) and was later developed into a method to detect tectonic signals from landscapes (Merritts and Vincent, 1989; Troiani and Della Seta, 2008; Font et al., 2010). The SL index is expressed as:

$$
\mathrm{SL}=(\Delta \mathrm{H} / \Delta \mathrm{L})^{*} \mathrm{~L}
$$

where $\Delta \mathrm{H}$ is the elevation difference, $\Delta \mathrm{L}$ is the difference in length, and $\mathrm{L}$ is the horizontal distance from the center of the reach to the drainage divide. This index easily detects slope 


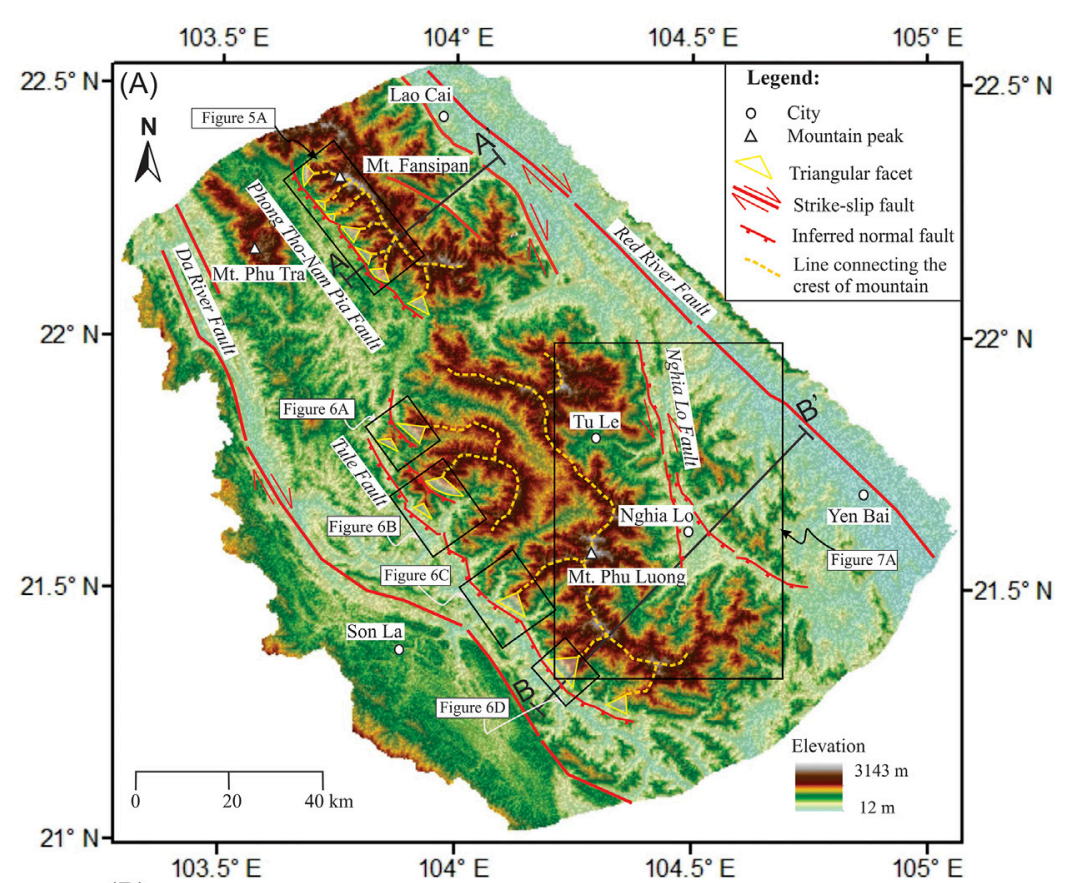

(B)
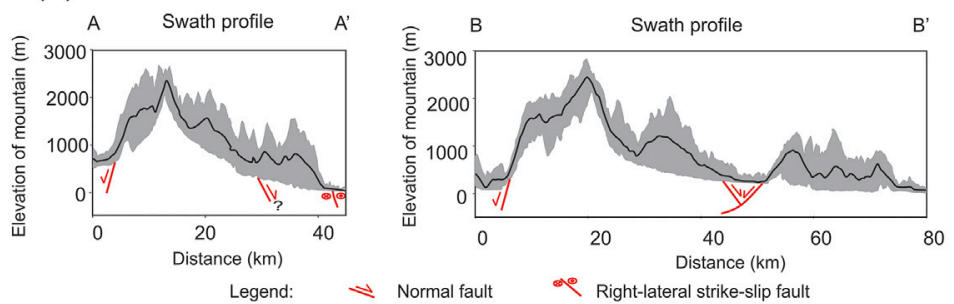

FIGURE 3 | (A) Topographic map showing drainage network, major active strike-slip faults complied from literature, and possible active normal fault inferred from topography and field observations. Thin blue lines indicate river system. Yellow triangles represent triangular facets. Dashed orange line is the line connecting the crests of the mountain ranges. Red line with directions indicate active strike-slip fault. Red lines with barbs represent the inferred normal faults. (B) Swath profiles with the strip width of $10 \mathrm{~km}$ on the cross-section lines A-A' and B-B'.

changes, so it is usually used to assess the impacts of tectonics and lithological contrasts on elevations. In a study area where the lithology is uniform, the SL index is widely used to detect differential tectonic uplift in active regions.

Analyses of $\mathrm{k}_{\mathrm{sn}}$ are also carried out for comparison with the results from the SL index. This index is established based on the relationship between the slope (A) and drainage area (S) of a river. The river slope the can be expressed as follows:

$$
\mathrm{S}=\mathrm{k}_{\mathrm{s}} \mathrm{A}^{-\theta}
$$

where $\mathrm{k}_{\mathrm{s}}$ is the steepness index and $\theta$ is the concavity. The basis of the method is that in active regions, tectonic forces can steepen rivers, which increases the river slope and impacts the drainage area. As a consequence, $\mathrm{k}_{\mathrm{s}}$ has a higher value in those areas than in places with nontectonic activity. Recently, $\mathrm{k}_{\mathrm{s}}$ has been widely used to detect the response of rivers to changes in tectonic activities (e.g., Wobus et al., 2006; Kirby and Ouimet, 2011; Chen et al., 2015). $k_{s}$ values can be determined by regressions of the slope and drainage area data (see Equation 2). This value has a mutual relationship with $\theta$. Therefore, to interpret the steepness index, the reference concavity $\left(\theta_{\text {ref }}\right)$ is used to normalize the $k_{s}$ value. In this study, a reference concavity $\left(\theta_{\text {ref }}\right)$ of 0.45 was used for all analyzed rivers. The normalized steepness index $\left(\mathrm{k}_{\mathrm{sn}}\right)$ can be expressed as:

$$
\mathrm{k}_{\mathrm{sn}}=\mathrm{k}_{\mathrm{s}} \mathrm{A}_{\text {cent }^{-(\theta r e f-\theta)}}
$$

where $A_{\text {cent }}$ is the area of the midpoint of the analyzed segment (Wobus et al., 2006). To easily discern anomalies, $\mathrm{k}_{\mathrm{sn}}$ values are commonly presented on map view by using MATLAB and ArcGIS software.

In addition to analyzing geomorphic indices, we also mapped knickpoint locations, which are considered as important locations to detect possible fault lineaments. Based on the longitudinal river profiles and slope-area data, the knickpoints are classified into two main groups: vertical-step and slope-break knickpoints (see Figure 4C and Kirby and Whipple, 2012; Wobus et al., 2006 for a detail discussion). Vertical knickpoints are related to discrete heterogeneities along river profiles and often 
A

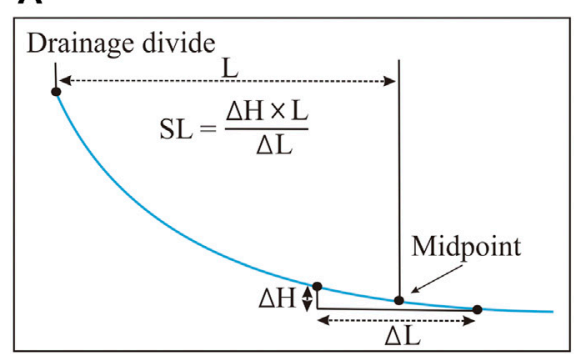

C

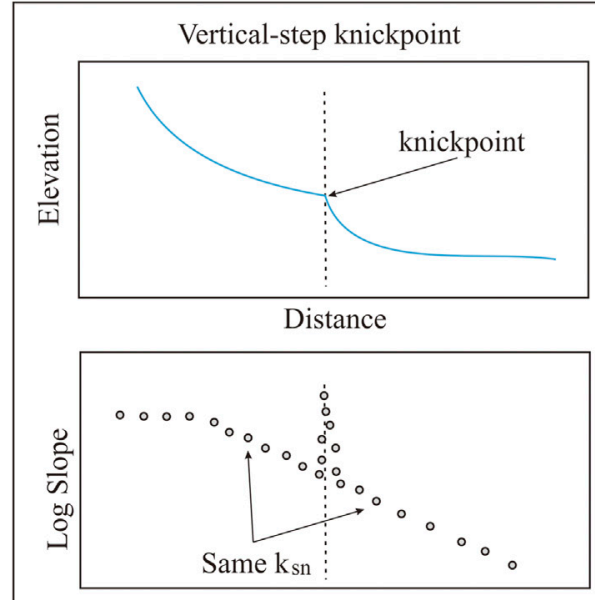

Log Area
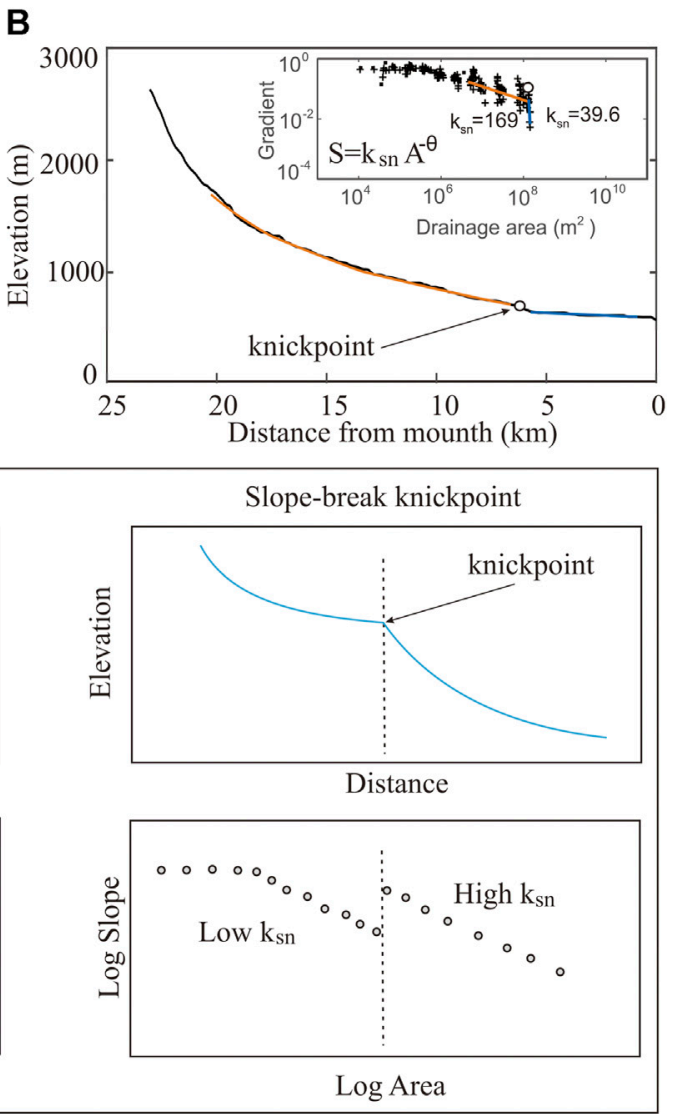

FIGURE 4 | (A) Measurement of the stream-length gradient index (SL); (B) Measurement of the normalized steepness index ( $\mathrm{k}_{\mathrm{sn}}$ ); (C) Classification of knickpoints in terms of both river profile and slope-area data (After Kirby and Whipple, 2012).

do not have tectonic significance (Kirby and Whipple, 2012). However, slope-break knickpoints are related to persistent changes in forces along rivers, which are possibly related to the tectonic activity of fault systems (e.g., Wobus et al., 2006; Kirby and Whipple, 2012). Therefore, mapping knickpoint locations plays an important role for tectonic interpretations in active regions.

\section{RESULTS}

\section{Observations From Digital Elevation Model and Field Surveys}

The prominent geomorphic feature in the Fansipan and Tule mountain ranges is an asymmetrical form of the entire ridge expressed by steeper, narrower hillslopes on the southwestern sides and wider, gentler hillslopes on the northeastern sides, as is shown in Figure 3. The crests of the mountain ranges are located close to the southwestern sides of the mountain ranges. The drainage systems are also different on the two sides of the mountain ranges. The rivers on the southwestern sides are shorter and steeper than those on the northeastern sides. Despite occupying a small percentage of the land surface, rivers serve as the most sensitive indicator of active tectonics when compared to other morphological features (Whipple, 2004). In active mountain ranges, rivers tend to be shorter and steeper on the flanks adjacent to faults, as was proven in the development of drainage systems in the western United States and central Greece (Leeder and Jackson, 1993). The short, steep rivers on the southwestern sides of the Fansipan and Tule mountain ranges are similar to the rivers in the western United States and central Greece, which probably suggest that active faulting is present on the sides of the mountain ranges. In addition to river systems, the markedly linear southwestern flanks of the Tule and Fansipan mountain ranges present impressive range-front scarps with well-developed triangular facets, as observed from the field and satellite images (Google Earth) (Figure 5, Figure 6). The triangular facets, which generally form due to erosion of fault-bound mountain ranges, are one of the most prominent geomorphic features that indicate active normal faulting (Burbank and Anderson, 2011). The steep triangular facets along the southwestern flanks of the Fansipan and Tule mountain ranges resemble those described in tectonically active range fronts elsewhere, such as in northern Norway (e.g., Osmundsen et al., 2009) and eastern Pamir (e.g., Brunel et al., 1994). Therefore, it is possible that the pattern of steep triangular facets on the 


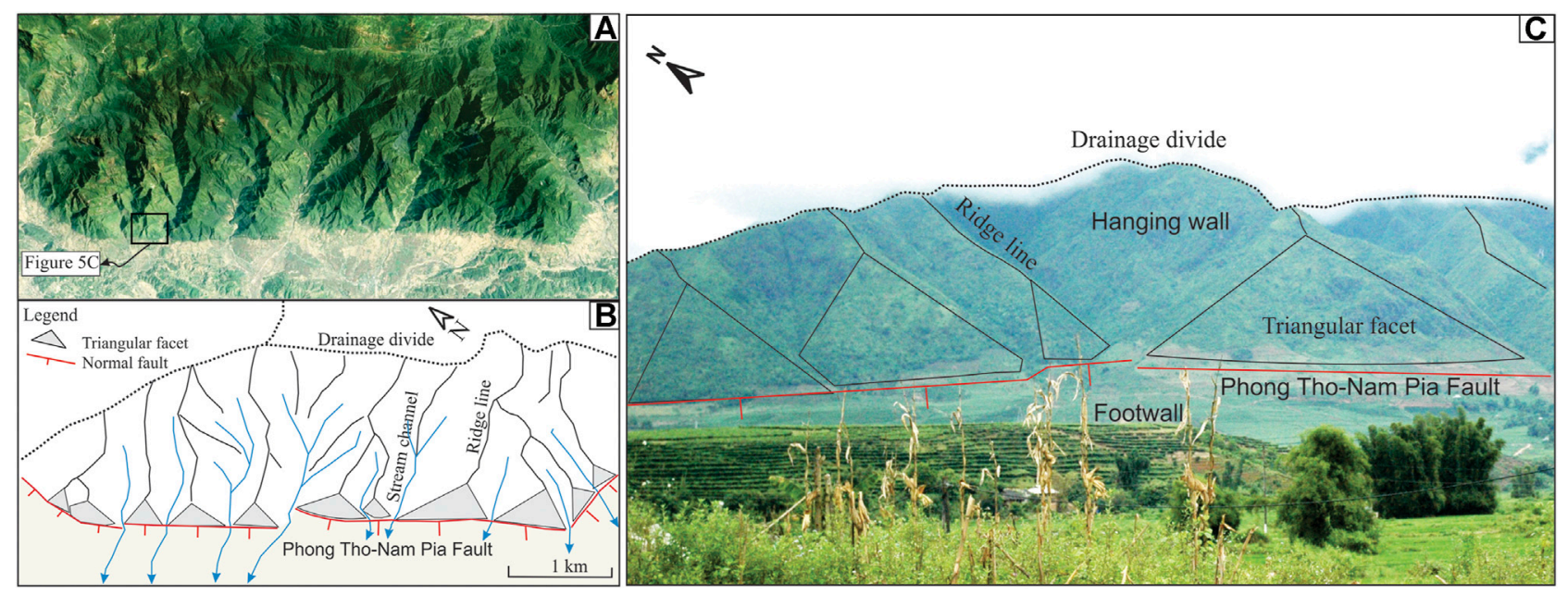

FIGURE 5 | (A, B) Satellite imagery (from Google Earth, December 18, 2019) and sketched map showing triangular facet pattern on the southwestern side of the Fasipan mountain range (see Figure $\mathbf{3}$ for location); (C) Field photograph showing geomorphic indicators of possible active normal fault along the Phong Tho-Nam Pia Fault.

southeastern sides of the Fansipan and Tule mountain range is associated with active normal faulting.

In the southeastern part of the Tule mountain range, a transtensional-like structure was found in the Nghia Lo Basin (Figure 7A). Left-lateral movements appear to have created river offsets that are easily observed in the Ngoi Hut and Ngoi Thia Rivers. Our mapping results show left-lateral offsets of up to $15 \mathrm{~km}$ in the Ngoi Thia River and $18 \mathrm{~km}$ in the Ngoi Hut River (Figures $\mathbf{7 B}, \mathbf{C}$ ). In addition to left-lateral movement inferred from river networks, traces of normal fault lineaments can also be mapped using $3 \mathrm{D}$ perspective views derived from the 12.5-m DEM (Figure 7D). The triangular facets are probably related to active normal faulting and have been observed on both sides of the Nghia Lo Basin. It seems that transtensional displacement, as indicated by both normal and strike-slip movements (Figure 7E), is probably a driving mechanism for basin formation and evolution in the Nghia Lo area. Furthermore, field surveys also carried out to double check our interpretations of faults derived from the DEM data. In the field, evidence for transtensional displacement, as presented by strike-slip motion with normal component, has been observed in the outcrop near Nghia Lo town (Figure 8). Based on the morphological characteristics of the river system, triangular facet pattern, youthful landform, and observations of rock offsets and fault slickensides, the inferred normal and strike-slip faults have been mapped along the southwestern side of the mountain ranges and the Nghia Lo Basin, as shown in Figure 3.

\section{Geomorphic Analyses \\ Stream-Length Gradient Index}

The SL index is calculated for every point at distances of $2 \mathrm{~km}$ along the length of the main trunk of each analyzed river. A map of interpolated SL values is shown in Figure 9. On the interpolated SL map, the SL values range from 0 to more than
$900 \mathrm{~m}$. A significant correlation was not found between lithology and the SL index (see Figures 2, 9). High SL index values have been documented for all rock types exposed in the study region, such as intrusive igneous rocks (on the SW side and some on the NE side of the Fansipan mountain range), extrusive igneous rocks (on the SW side of the Tule mountain range), metamorphic rocks (on the NE side in the southern part of the Fansipan mountain range), and sedimentary rocks (south of the Da River Fault). Instead, the SL index values increase toward the inferred normal faults, such as the extremely high values (e.g., higher than $900 \mathrm{~m}$, marked by red color in Figure 9) that are adjacent to the inferred normal faults such as the Tule Fault, Nghia Lo Fault and Phong Tho-Nam Pia Fault, as well as close to the strike-slip Da River Fault. High SL index values are not found along the RRF, except for the area close to the $\mathrm{NE}$ side of the Fansipan mountain range.

\section{Normalized Steepness Index (ksn) and Knickpoint Distribution}

Analyses of $\mathrm{k}_{\mathrm{sn}}$ values were carried out for the main rivers, as indicated in Figure 10. The results of estimated $\mathrm{k}_{\mathrm{sn}}$ values for 15 rivers are presented in Figure 11. Each analyzed river has two to four different $\mathrm{k}_{\mathrm{sn}}$ values that are associated with different segments separated by main knickpoints. The results from our study indicate that the $\mathrm{k}_{\mathrm{sn}}$ values vary from $\sim 13 \mathrm{~m}^{0.9}$ to more than $350 \mathrm{~m}^{0.9}$, as shown in Figure 11. However, despite such variations, with the exception of river $\# 15$, the highest $k_{s n}$ values were found for the second segments from river confluences. In river \#15, the highest $\mathrm{k}_{\mathrm{sn}}$ value of $136 \mathrm{~m}^{0.9}$ occurred in the last segment, and the lowest $\mathrm{k}_{\mathrm{sn}}$ value of $33.9 \mathrm{~m}^{0.9}$ occurred in the third segment. We also overlaid the $\mathrm{k}_{\mathrm{sn}}$ values on the topographic map to obtain tectonic information. In general, high $\mathrm{k}_{\mathrm{sn}}$ values were located on the footwalls of inferred normal faults, whereas low $\mathrm{k}_{\mathrm{sn}}$ values were mostly 

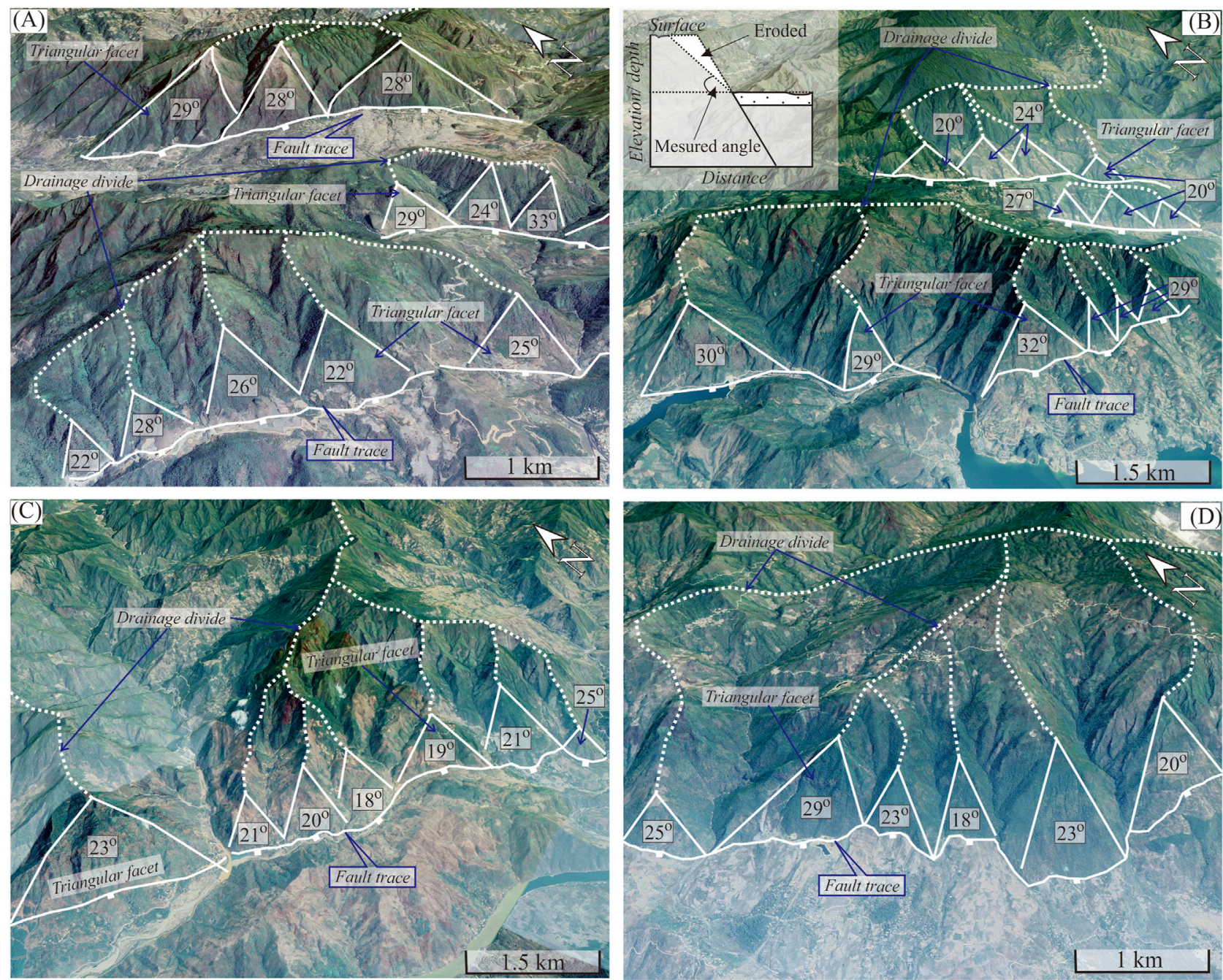

FIGURE 6 | Satellite imagery (downloaded from Google Earth, December 18, 2020) shows an impressive range-front scarp with triangular facets on the southwestern flank of Tule area. While line with barbs indicates inferred normal fault. White line presents triangular facets. White dash line shows drainage divides. Number refers to slope value (in degree).

concentrated on their hanging walls. In rivers \#9 to \#12, where a portion of the RRF cuts the mountain range, the $\mathrm{k}_{\mathrm{sn}}$ values on the two sides of the fault are different, with higher values on the west side and lower values on the east side. It seems likely that such variations in $\mathrm{k}_{\mathrm{sn}}$ values are associated with the tectonic forces that underly the high mountain range.

Based on the longitudinal river profiles and slope-area graphs, 26 major knickpoints were identified along the analyzed rivers. The types of knickpoints and their distributions are shown in Figures 11, 12. Most of the knickpoints are spatially associated with locations of homogeneous lithology, with only a few exceptions for some knickpoints in rivers \#5, \#8, \#12, \#14, and \#15 (Figures 11, 12). By following the method described in the study of Wobus et al. (2006), the knickpoints in this study were also classified into vertical knickpoints and slope-break knickpoints. All of identified knickpoints in the study area are slope-break knickpoints and most of them are spatially correlated with the locations of the inferred normal and strike-slip faults (Figure 12).

\section{DISCUSSIONS}

\section{Tectonic Signals From Geomorphic Indices}

The morphological features of rivers are products of both tectonic and nontectonic factors (Burbank and Anderson, 2011). Nontectonic factors such as contrasting lithologies and climate variations, which may lead to differences in river gradients, can affect the values of the applied geomorphic index. Therefore, to interpret tectonic information from geomorphic indices, we first need to consider the potential influences of 

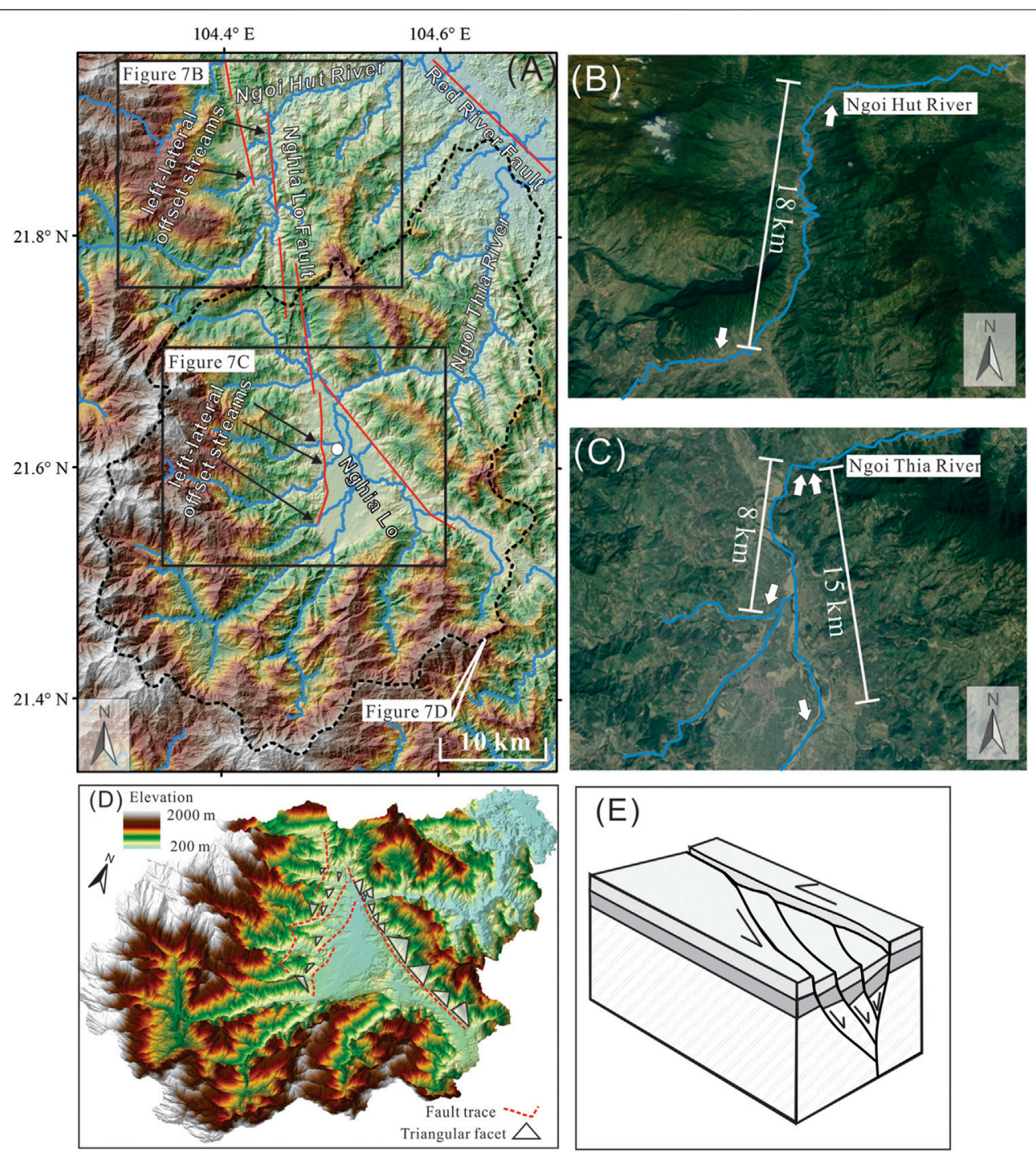

FIGURE 7 | (A) $12.5 \mathrm{~m}$ DEM imagery showing topographic features and fault systems in the northeastern side of the south part of the Tule mountain range (for location see in Figure 3); (B, C) River offsets in Ngoi Hut and Ngoi Thia River imply left-latearal movements along the Nghia Lo fault (images from Google Earth, November 11, 2020); (D) 3-D image from $12.5 \mathrm{~m}$ DEM data showing possible fault traces and patterns of triangular facets on two sides of Nghia Lo basin that probably indicate normal faulting in this area; (E) A proposed model for formation of Nghia Lo basin with both strike-slip and normal displacements.

other factors. Climate variations, especially changes in precipitation, may influence geomorphic index values and can affect knickpoint formation. However, in the Fansipan and Tule mountain ranges, the subtropical monsoon climate that is characterized by hot and humid environments dominates the entire area. The monthly average precipitation is rather uniform for the whole study area, with the lowest value of $\sim 50 \mathrm{~mm}$ in January and highest value of $\sim 1,000 \mathrm{~mm}$ in July (Phan et al., 2009). Therefore, the climate does not appear to be a cause for the observed differences in the SL and $k_{s n}$ values in the Fansipan and Tule mountain ranges.

Variations in lithology may affect the SL values when rivers flow across contacts with different rock types with different rock strengths (Hack, 1973). Thus, we must consider the SL values based on the effects of lithological variations. The results of our study show that high SL index values are observed for most rock types, such as intrusive igneous rocks (on the SW side and some on the NE side of the Fansipan mountain range), extrusive igneous rocks (on the SW side of the Tule mountain range), metamorphic rocks (on the NE side in the southern part of the Fansipan mountain range), and sedimentary rocks (south of the Da River Fault). It is possible to infer that lithology has a limited impact on the spatial patterns of SL values in the Fansipan and Tule mountain ranges.

Similar to the SL values, the $\mathrm{k}_{\mathrm{sn}}$ values are probably affected by variations in lithology along the rivers. Thus, to determine the potential influence of lithology variations, we overlaid the lithological mapping results on the $\mathrm{k}_{\mathrm{sn}}$ value distribution, as shown in Figure 11, and no clear correlation can be observed. 

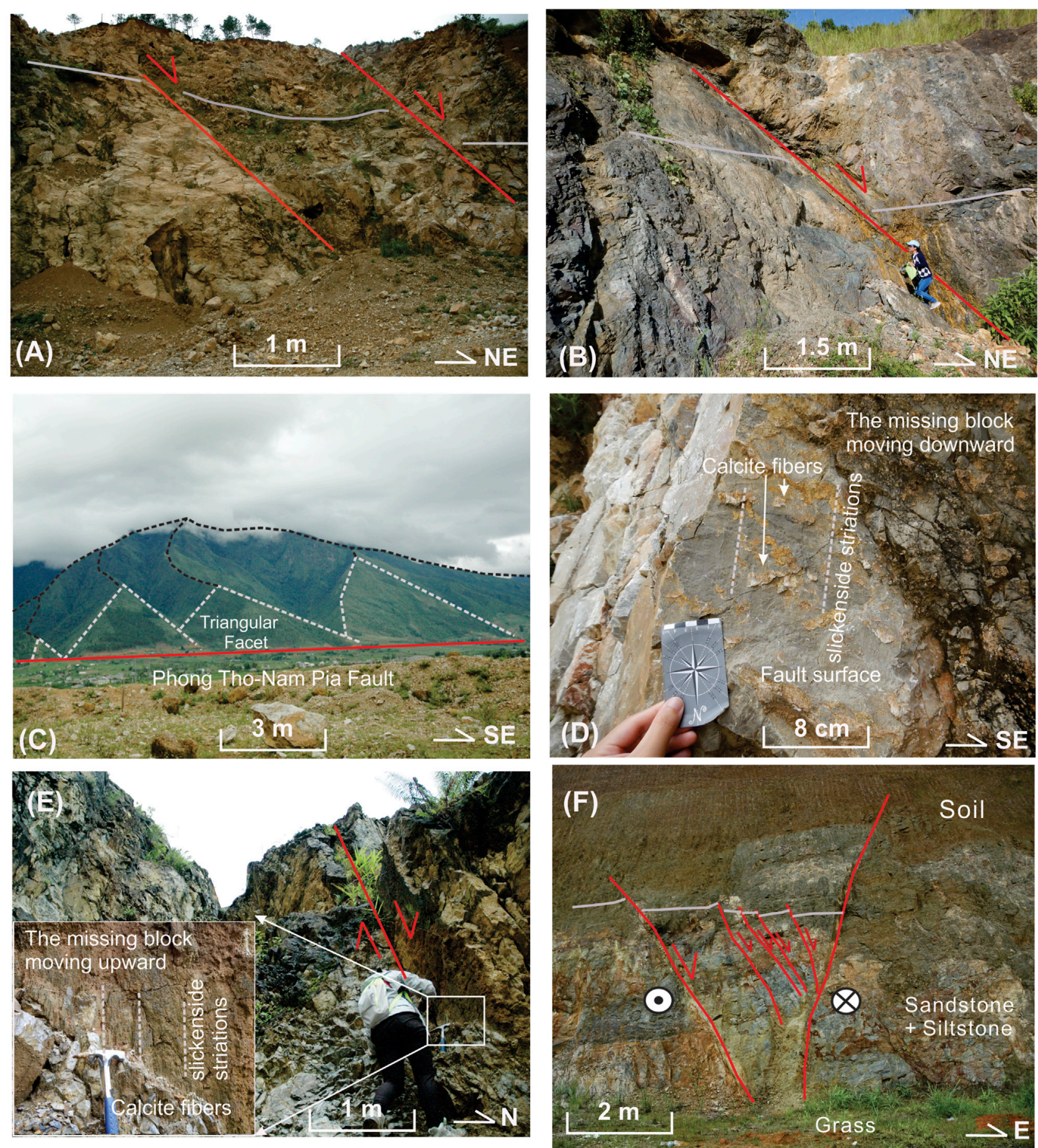

FIGURE 8 | (A, B) Normal faults exposed along roadcuts in outcrops VN01 and VN04, respectively; (C) Filed photo taking in the mountain front of the SW side of the Fansipan mountain range showing triangular facet pattern; (D, E) Calcite slickensides on the fault planes indicating normal fault movement in outcrops VN02 and VN03, respectively; (F) Negative flower structure in outcrop VN05 shows extensional movement with a combination of normal and left-lateral movements in the Nghia Lo area.

The $\mathrm{k}_{\mathrm{sn}}$ values do not vary significantly across lithologies but may differ within the same rock type at the locations of potential faults. In addition, the knickpoints do not seem to be correlated with variations in lithology, and most knickpoints are located in locations with homogeneous lithology (Figures 11, 12). Thus, lithology contrasts do not seem to exert 


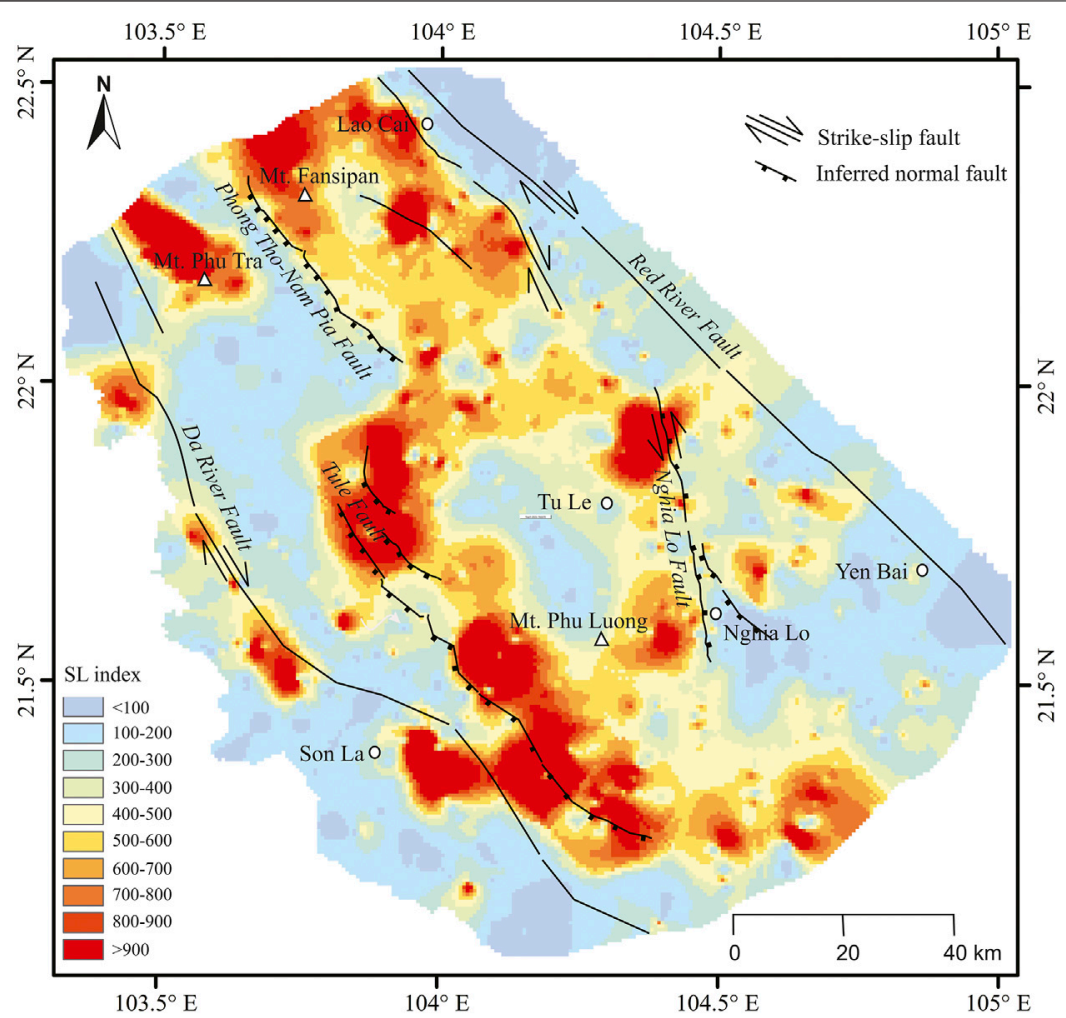

FIGURE 9 | The map showing the stream-length gradient index (SL) values within and surrounding the Fansipan and Tule mountain ranges.

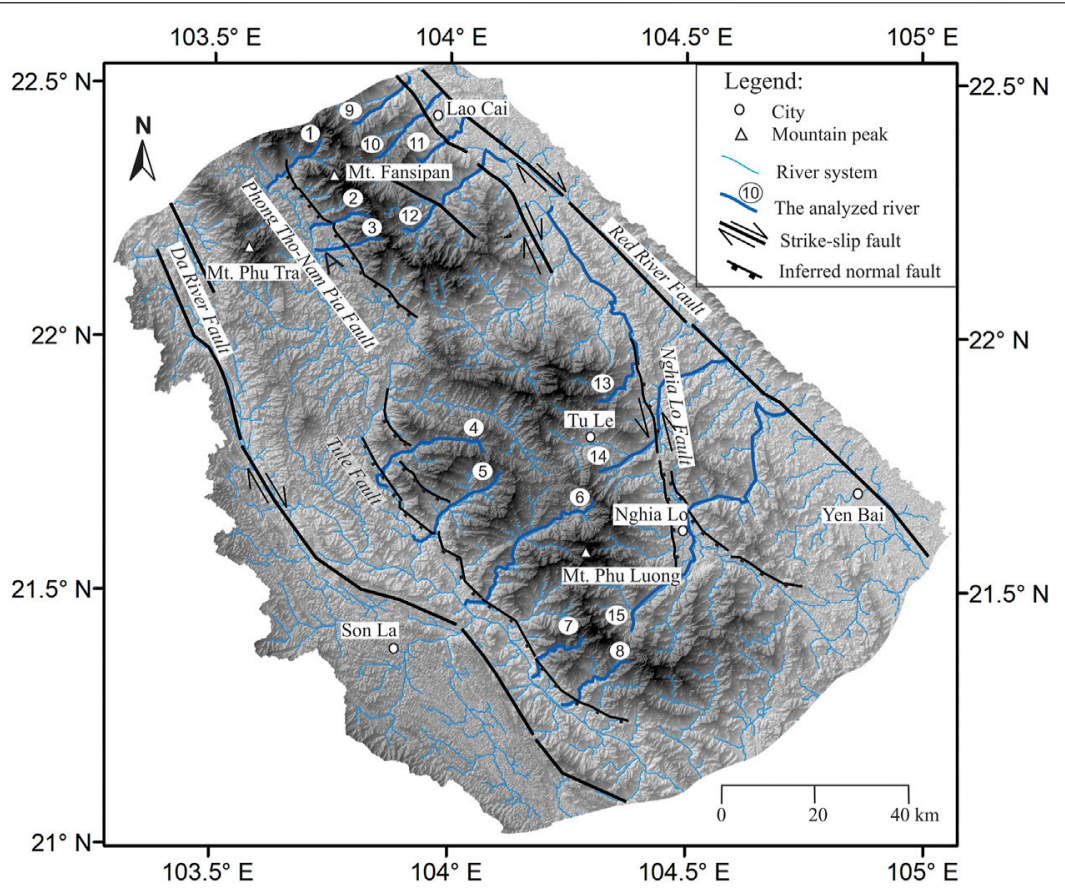

FIGURE 10| Topographic map showing the distribution of major faults (black lines) within the Fansipan and Tule mountain ranges and adjacent areas. The thin blue lines show the river systems. The thick blue line shows the rivers used for the river profile and normalized steepness index analyses. The number before the river labels the name of the analyzed river. 

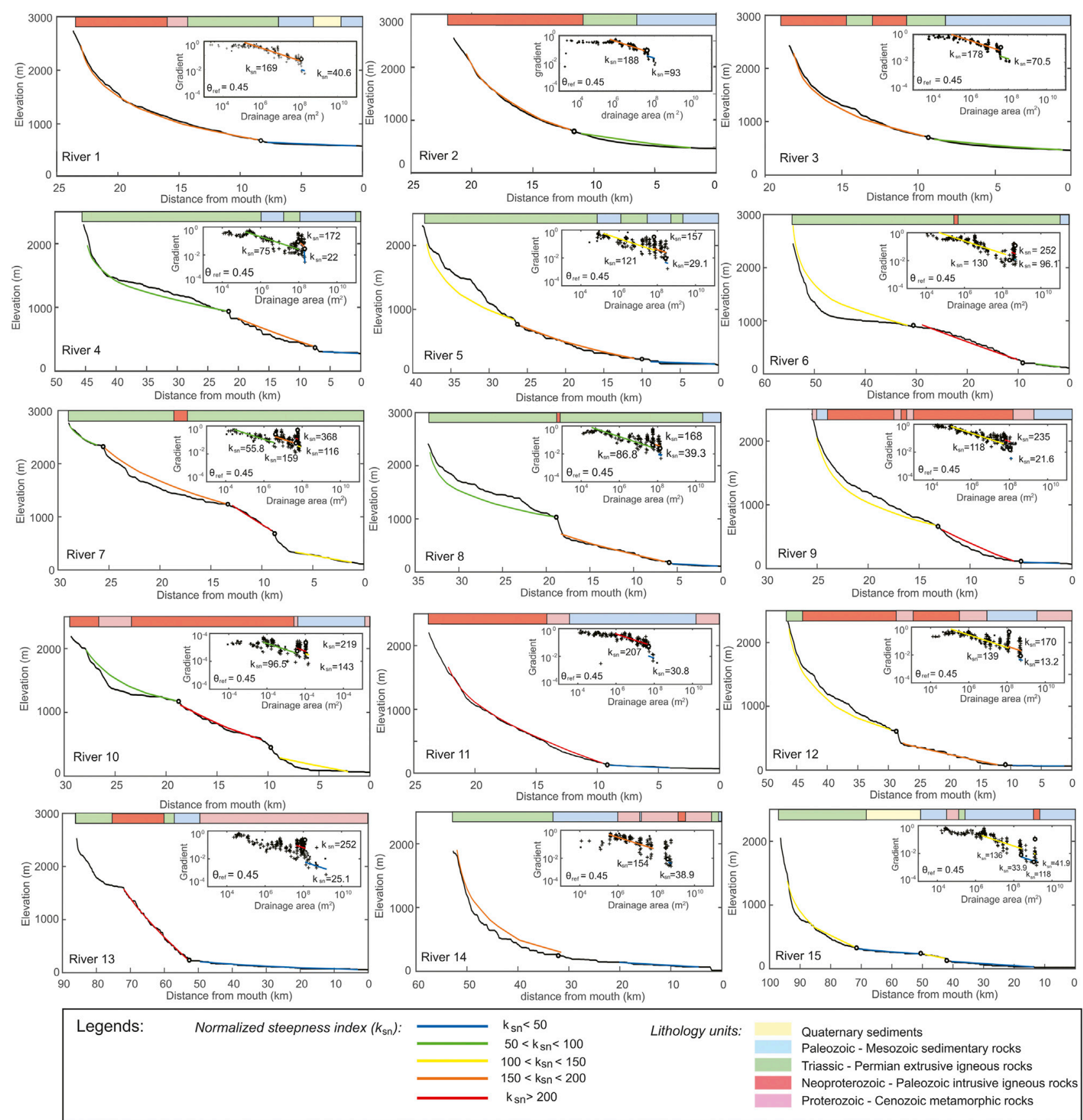

FIGURE 11 | Longitudinal river profiles and the values of the normalized steepness index $\left(\mathrm{k}_{\mathrm{sn}}\right)$ along the analyzed rivers. The lithology units where the river flows through are presented above the longitudinal river profiles with the color corresponding to the same color as shown in geological map (Figure 2). Upper right rectangular represents log-log plots of gradient and drainage area data. The locations of the analyzed rivers are shown in Figure $\mathbf{3}$. The back circles on both the longitudinal river profiles and log-log plots of gradient and drainage area represent knickpoints. The values of the normalized steepness index are indicated by different colored lines.

conspicuous effects on $\mathrm{k}_{\mathrm{sn}}$ value variations and knickpoint formation in the study area.

Therefore, tectonic processes are the main controlling factor for the variations in SL and $k_{s n}$ in the study area. In other words, the differences in landscape characteristics as well as geomorphic index values observed in our study possibly reflect tectonic activities, e.g., the fault systems underlying mountain ranges. 


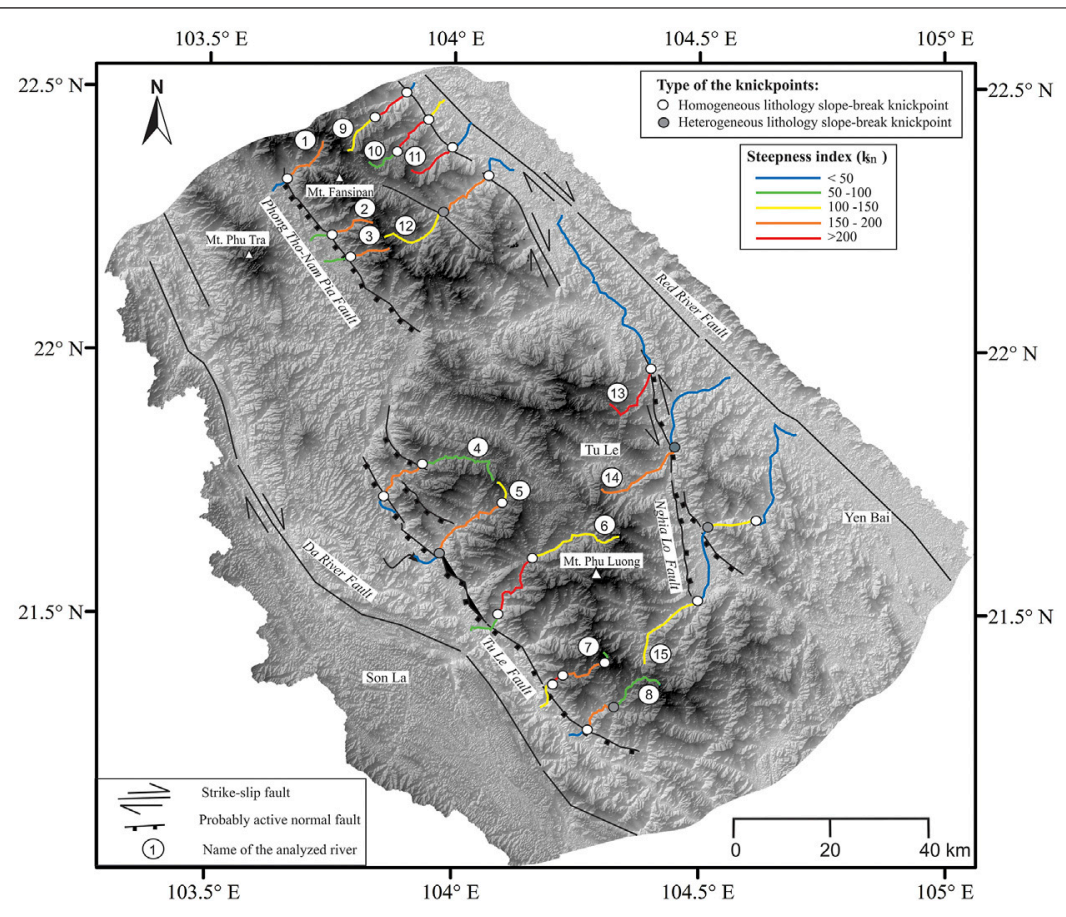

FIGURE 12 | Topographic map showing distribution of the knickpoints as identified in Figure $\mathbf{1 1}$ and the normalized steepness index ( $\mathrm{k}_{\mathrm{sn}}$ ) values along the analyzed rivers. The values of $\mathrm{k}_{\mathrm{sn}}$ are indicated by different colors, corresponding to $\mathrm{k}_{\mathrm{sn}}$ color scale in Figure $\mathbf{1 1 .}$

\section{New Constraints on Active Movements of the Fansipan and Tule Mountain Ranges}

The Fansipan and Tule mountain ranges are located in the southeasternmost region of the Himalayan syntaxis, which is spatially associated with the Tibetan Plateau through the RRF, an important structure related to the Cenozoic collision of the Indian and Eurasian blocks (Allen et al., 1984; Replumaz et al., 2001). Many studies have been carried out in the Fansipan and Tule mountain ranges that have focused on igneous geochemistry and petrogenesis (e.g., Lan et al., 2001; Dung et al., 2012; Usuki et al., 2015; Shellnutt et al., 2020). However, the knowledge of active tectonic deformation in these regions remains limited. A GPS study (Trân et al., 2013) was performed to determine and map active and potential active faults in northern Vietnam. However, the uncertainty of the vertical component of the GPS velocity is too large to be useful for this study in the Fansipan and Tule mountain ranges. Thus, one of the principal efforts of this work was to use geomorphic indices and characteristics to constrain the active deformations of the high mountain ranges in northern Vietnam.

The Fansipan and Tule mountain ranges show asymmetrical form of topography with different geomorphic features on the SW and NE sides of the ranges. It is possible that the asymmetrical form of topography relates to the underlying structures within asymmetrical fold belts. However, in the study area, the regional geology and our research findings do not support a folding system for the asymmetrical form of the mountain ranges. The different geomorphic features on the SW and NE sides of the Fansipan and Tule mountain ranges likely reflect active fault movements as suggested in this study. . The rivers on the SW sides of the Fansipan and Tule mountain ranges are shorter and steeper than those on the NE sides, which possibly indicate higher uplift rates on the SW sides of the mountain ranges. Steep triangular facets, which are typical landforms of normal faults (Stewart and Hancock, 1990), were also observed on the SW sides of the mountain ranges. The short, steep rivers together with the triangular facet patterns are probably a response to the recent tectonic activity of normal faults on the southwestern sides of the Fansipan and Tule mountain ranges. In the central Tule mountain range, river systems indicative of left-lateral offset can be observed by using satellite images (Google Earth), particularly in segments along the Ngoi Hut and Ngoi Thia Rivers. Moreover, in the Nghia Lo region, the triangular facet patterns are similar to those that result from normal faulting in areas with extensional tectonism. The northto-northeast trend of the inferred Nghia Lo fault is similar to that of the Dien Bien Phu fault, which is an active strike-slip fault with left-lateral motion and a normal slip component (Lai et al., 2012; Trần et al., 2013). Furthermore, the left-lateral oblique movements of the north-to northeast-trending faults in the Nghia Lo fault and Dien Bien Phu fault are in good agreement with the stress pattern of a permutation of $\sigma_{1} / \sigma_{2}$ under the same extensional stress regime of NE-SW $\sigma_{3}$ as proposed in Dinh et al. (2020). The Nghia Lo fault should therefore be considered as an active fault with recent movement consisting of left-lateral oblique faulting with both normal and strike-slip movements. As the mountain ranges are bounded by right-lateral strike-slip faults of the Da River Fault and Red River Fault, the possibility that the left-lateral Nghia Lo fault could be a result from the 


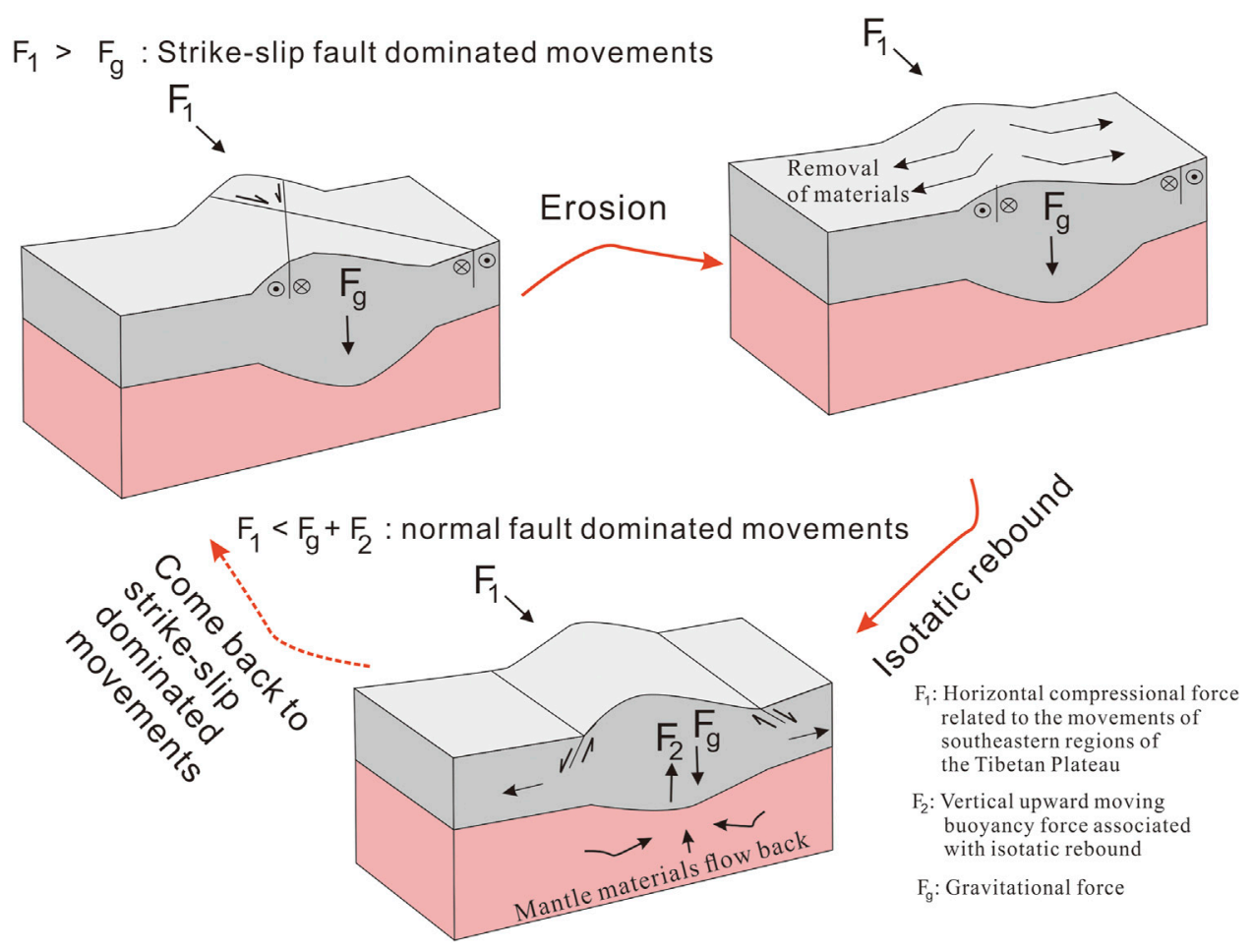

FIGURE 13 | Cartoon of the interpreted model for repeated cycles of normal and strike-slip faulting as a result of interaction between tectonics and erosion in the Fansipan and Tule mountain ranges.

rotation of fault-bounded blocks can be considered. If this possibility occurs, we expect to observed a set of small leftlateral strike-slip fault and rotated sigmoid structures in the deformed zone as shown in the classic study of Schreurs (1994). However, we did not find such patterns of deformed structures in the Fansipan and Tule mountain ranges. Thus, we consider the possibility of the rotation of fault-bounded block caused left-lateral strike-slip movement along the Nghia Lo fault is not likely to happen. Overall, by combining our observations and knowledge from the literature, we have mapped the potential active faults within and surrounding the Fansipan and Tule mountain ranges, as shown in Figures 3, 9, 12.

The SL index pattern also fits well with the fault systems inferred from topography and field observations. In particular, the SL index values that indicated high uplift rates are mostly distributed in the footwalls of the inferred normal faults. However, not all faults are spatially associated with locations with high SL values. As seen in Figure 9, high SL values are mostly lacking in the RRF. There are two possibilities for this lack of high SL values. First, this probably indicates the absence of recent movement on the RRF. The second possible reason is that the RRF is a strike-slip fault dominated by horizontal movement instead of by vertical movement, while minor vertical movement causes limited changes in uplift rates on both walls of the fault, which results in low SL values along the RRF. High SL values were also found along the Da River Fault and along the north branch of the RRF adjacent to the Fansipan mountain range. These probably indicate that the faults are possibly oblique-slip faults with both strike-slip and dip-slip motions instead of being pure strike-slip faults.

Similar to the SL index, the results from the $\mathrm{k}_{\mathrm{sn}}$ index and knickpoint distribution seem to correspond with the faults that were inferred from topography and field observations. In general, most of the knickpoints in the downstream regions are spatially associated with fault locations. The river profile analysis also indicates that most of these identified knickpoints are slope-break knickpoints, which suggests a possible change in tectonic forces along rivers. In contrast to the knickpoints in the downstream regions, most knickpoints in the upstream regions are not associated with fault locations. A potential explanation for this phenomenon is that these knickpoints possibly formed as a result of interactions among bedrock and river systems instead of being related to the activities of fault systems. We also found that the general trend of $\mathrm{k}_{\mathrm{sn}}$ index values implying uplift rates was likely correlated with active fault movement. For most of the analyzed rivers, high values of $\mathrm{k}_{\mathrm{sn}}$ indicating relatively high uplift rates were recorded in the footwalls of the inferred normal faults, whereas low values of $\mathrm{k}_{\mathrm{sn}}$ suggesting relatively low uplift rates were found in the hanging walls. The systematic changes in these values likely reflect different uplift rates across the inferred normal faults, which indicate the presence of active slip.

Overall, the potentially active faults inferred from DEM and field observations match well with the results obtained from analyses of geomorphic indices and knickpoints. Such consistency provides important constraints on the tectonic movements of the Fansipan and Tule mountain ranges. The 


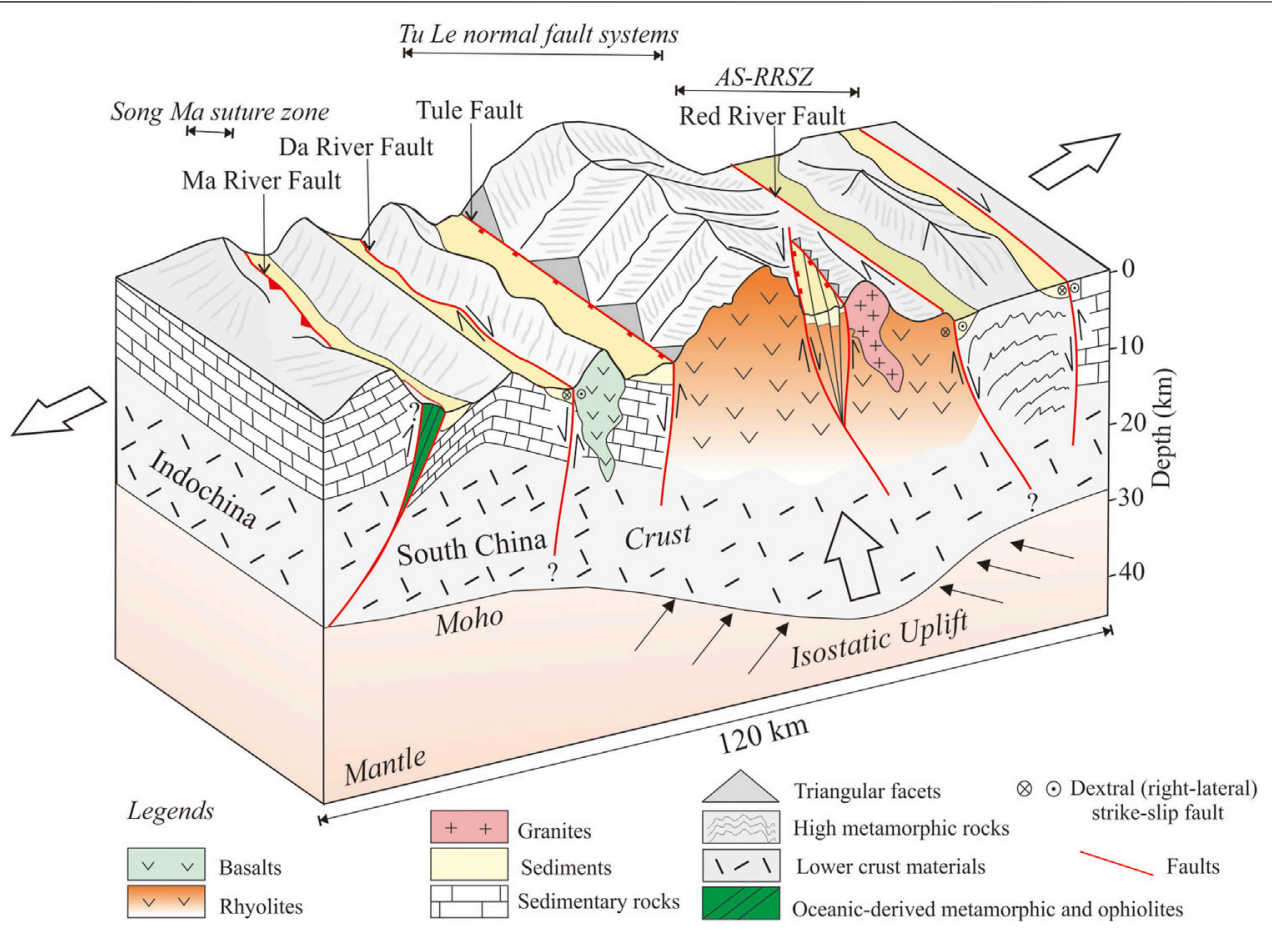

FIGURE 14 | Schematic 3-D diagram showing fault systems within and surrounding the study area. The uplift of the Fansipan and Tule mountain range was probably controlled by extensional tectonics that created the space in upper crust to make lower materials moving upward by isostatic rebound.

differences in the SL and $\mathrm{k}_{\mathrm{sn}}$ index values reflect the differences in rock uplift rates driven by the activities of fault systems that underlie the high mountain ranges. Recent tectonic deformation of the Fansipan and Tule mountain ranges is dominated by active movements along both normal and strike-slip faults under extensional tectonics.

\section{Tectonic Implications for Uplift of the Fansipan and Tule Mountain Ranges}

As mentioned in the Introduction section, the Fansipan and Tule mountain ranges are topographically high regions that mostly have exposed Permian-Triassic igneous rocks. Under intense weathering in the monsoon-affected areas, the Fansipan and Tule mountain ranges still stand high with peaks higher than 3,000 $\mathrm{m}$ above sea level. This therefore raises the question of why these mountain ranges are able to maintain such high elevations under intense weathering and erosion next to a strike-slip dominated fault, RRF. Our results indicate that the active movements of the Fansipan and Tule mountain ranges are dominated not only by strike-slip faults but also by normal faults, including the Phong Tho-Nam Pia and Tule normal faults and the Nghia Lo strike-slip fault with a normal slip component. Active movement of normal and strike-slip faulting was also found north of the Fansipan mountain range in the Lao Cai segment (Phan et al., 2019), within and surrounding the Fansipan mountain range (Dinh et al., 2020) and in the active RRF that is bounded by the Fansipan and Tule mountain ranges on the northeastern side (Replumaz et al., 2001). The horizontal velocity determined from the GPS network in northern Vietnam (Duong et al., 2013; Trần et al., 2013) suggested extensional movement in the Fansipan and Tule mountain ranges, that shows a significant consistency with the findings of this study. Based on our study and other published research, we suggest that the Fansipan and Tule mountain ranges and surrounding regions are subject to extensional mechanisms with a combination of both normal and strike-slip faulting, which contribute to their pronounced uplift.

In the majority of cases, mountain building processes usually go through two stages: the constructional stage as crustal thickening and the destructional stage as crustal thinning (Stephenson and Lambeck, 1985); the Fansipan and Tule mountain ranges are no exception. The recent findings of active extensional structures in these mountain ranges prompt us to relate the extensional mechanism to the second stage of the mountain building process when the geodynamics changed from crustal thickening to crustal thinning. The observed strike-slip movements of the faults are probably related to the current movement of crustal materials from the Tibetan Plateau into the southwestern China regions, as supported by field paleostress reconstruction (Dinh et al., 2020) and the GPS velocity field (Shen et al., 2005). As the Fansipan and Tule mountain ranges are under subtropical monsoon climates, erosional processes also play an important role in not only shaping the topography but also in altering crustal mass balance at a million-year scale, which leads to isostatic rebound and may produce strong rock uplift. Mechanistically, isostatic rebound of thick material in the lower crust is similar to an iceberg that is underneath the 
ocean: when the upper material of the crust is removed, the crust rebounds, and mantle materials flow back (Stern et al., 2005; Champagnac et al., 2007). The flow of mantle materials together with the gravitational force of thick mountain ranges causes crustal stretching that is accompanied by normal fault systems. Normal faulting will stop and switch to strike-slip faulting when the stretching force is lower than the horizontal compressional force produced by tectonic movements on the Tibetan Plateau. The cycles of strike-slip and normal faulting would continue as a result of the interaction between tectonics and erosion after a period of time. Such cycles of alternating strike-slip and normal faulting (Figure 13) produced the stress permutations discovered and discussed in Dinh et al. (2020). From these interpretations, we propose that the recent uplift of the Fansipan and Tule mountain ranges is controlled by extensional tectonics (Figure 14) with alternations of normal and strike-slip faulting as a consequence of the interactions between the tectonics induced by movements of the southeastern regions of the Tibetan Plateau and erosional processes.

The findings of both normal and strike-slip faulting in this study may provide constraints on how the crustal lithosphere deforms in the Tibetan Plateau and its surrounding regions where several competing dynamic models have been proposed. One model regards the lithosphere as rigid and deformation mainly concentrates in plate boundaries delineated by largescale and high slip rate of strike-slip faults (named as the indentation-extrusion model; e. g., Armijo et al., 1989; Leloup et al., 2001; Tapponnier, 2001; Tapponnier et al., 1982). Another model suggests that thickened crustal lithosphere, e.g., the Tibetan plateau, behaves as a ductile medium where the mid-to lower crust is so weak that the upper crustal deformation is decoupled from the mantle (named as the mid-to lower crustal flow model; e.g., Burchfiel, 2004; Royden, 1997; Shen et al., 2005). The observations of upper crust in the Fansipan and Tule mountain ranges seem to be consistent with the one proposed in the mid-to lower crustal flow model. We found that the deformation of the Fansipan and Tule mountain ranges is not limited in block boundaries with dominated horizontal movements as proposed in the indentation-extrusion model, but distributed across many active or potential active faults with both vertical and horizontal movements. Additionally, our field investigation indicated that nearly all of observed faults in this area show brittle deformation. It is possible that the faults have formed at shallow depths which are similar to those mentioned in the mid-to lower crustal flow model. We recognize that the indentation-extrusion model is an important model for understanding tectonic evolution of the Tibetan plateau and its surrounding regions. However, instead of considering the deformations in two-dimensions, it is suitable to interpret them in three-dimensions, especially in the thickened crustal regions such as the Tibetan plateau region or the Fansipan and Tule mountain ranges. We believe more measurements of deformation and rheology of the lower crust should be done to further constrain the tectonic dynamics of this region.

\section{CONCLUSION}

We used observations from satellite images (Google Earth), field data and river morphology analyses, including the streamlength gradient index $(\mathrm{SL})$, normalized steepness index $\left(\mathrm{k}_{\mathrm{sn}}\right)$, and knickpoint distributions, to identify possible active faults in the Fansipan and Tule mountain ranges in northern Vietnam. Our topographic observations from Google Earth imagery, 30$\mathrm{m}$ and 12.5-m DEM data, and field surveys suggest notable active normal and strike-slip faults within and surrounding the Fansipan and Tule mountain ranges, e.g., the Phong Tho-Nam Pia fault, Tule fault, and Nghia Lo fault. The results from the geomorphic indexes used appear to be in good agreement with the topography observations. The high values of the SL and $\mathrm{k}_{\mathrm{sn}}$ indices are spatially associated with the footwalls of the inferred normal faults. The distributions of the analyzed knickpoints are also spatially related to the fault locations. We found that climate and lithology have negligible effects on the spatial variation in geomorphic index values; thus, the geomorphic index patterns probably reflect the active movements of fault systems that underly the Fansipan and Tule mountain ranges. By combining these results, we suggest that the active movements of the Fansipan and Tule mountain ranges are dominated by extensional tectonics with a combination of both normal and strike-slip faults. We therefore propose that the recent uplift of the Fansipan and Tule mountain ranges may be related to the last stage of orogenic evolution when the dynamics changed from crustal thickening to crustal thinning. Within monsoon-affected regions, the influence of erosion plays an important role in the driving mechanism for the uplift of mountain ranges. Unloading of materials in the upper crust by erosion causes materials in the lower crust to move upward due to isostatic rebound to maintain the high elevations of mountain ranges for a long span of geological time.

\section{DATA AVAILABILITY STATEMENT}

The original contributions presented in the study are included in the article/Supplementary Material, further inquiries can be directed to the corresponding author.

\section{AUTHOR CONTRIBUTIONS}

Conceptualization: T-HD and Y-CC; Analysis: T-HD and Y-CC; Visualization: T-HD and Y-CC; Funding Resources: Y-CC and CTC; Writing original draft: T-HD; Writing review and editing: T-HD, Y-CC and C-TC; Supervision: Y-CC. All authors have read and agreed to the submitted version of the manuscript.

\section{FUNDING}

This research was supported by the Taiwan Ministry of Science and Technology grant No. MOST-108-2116-M-001-008, MOST109-2116-M-001-020 and the thematic research project AS-TP- 
108-M08 of Academia Sinica to Y-CC, as well as MOST-1102116-M-008-008 to C-TC.

\section{ACKNOWLEDGMENTS}

We are grateful to Chung-Pai Chang, Tung-Yi Lee, and MengWan Yeh for their valuable comments and supports.

\section{REFERENCES}

Allen, C. R., Gillespie, A. R., Han, Y., Sieh, K. E., Buchun, Z., and Chengnan, Z. (1984). Red River and Associated Faults, Yunnan Province, China: Quaternary Geology, Slip Rates, and Seismic hazard. GeoScienceWorld 95 (6), 686-700. doi:10.1130/00167606(1984) $95<686$ :RRAAFY > 2.0.CO;2

Armijo, R., Tapponnier, P., and Han, T. (1989). Late Cenozoic Right-Lateral StrikeSlip Faulting in Southern Tibet. J. Geophys. Res. 94 (B3), 2787-2838. doi:10.1029/JB094iB03p02787

Brunel, M., Arnaud, N., Tapponnier, P., Pan, Y., and Wang, Y. (1994). Kongur Shan normal Fault: Type Example of Mountain Building Assisted by Extension (Karakoram Fault, Eastern Pamir). Geol 22 (8), 707-710. doi:10.1130/00917613(1994)022<0707:ksnfte>2.3.co;2

Burbank, D. W., and Anderson, R. S. (2011). Tectonic Geomorphology. J. Wiley \& Sons. Available at: https://books.google.com.tw/books?hl=en\&lr=\&id=83FuAvtS wE4C\&oi=fnd\&pg $=$ PT7\&dq=tectonic + geomorphology+burbank\&ots=Sjyx $5 \mathrm{c} 3$ _ YQ\&sig=cCIbbnH50jD5uirCYqyBUEp9hGg\&redir_esc $=\mathrm{y} \# \mathrm{v}=$ onepage\&q= tectonic geomorphology burbank\&f=false.

Burchfiel, B. C. (2004). New Technology; New Geological Challenges. GSA Today 14, 4-10. doi:10.1130/1052-5173(2004)014<4:panngc >2.0.co;2

Byrne, T., Chan, Y.-C., Rau, R.-J., Lu, C.-Y., Lee, Y.-H., and Wang, Y.-J. (2011). "The Arc-Continent Collision in Taiwan," in Arc-Continent Collision (Berlin, Heidelberg: Springer), 213-245. doi:10.1007/978-3-540-88558-0_8

Carter, A., and Clift, P. D. (2008). Was the Indosinian Orogeny a Triassic Mountain Building or a Thermotectonic Reactivation Event? Comptes Rendus Geosci. 340, 83-93. doi:10.1016/j.crte.2007.08.011

Champagnac, J. D., Molnar, P., Anderson, R. S., Sue, C., and Delacou, B. (2007). Quaternary Erosion-Induced Isostatic Rebound in the Western Alps. Geol 35, 195-198. doi:10.1130/G23053A.1

Chen, C.-T., Chan, Y.-C., Lo, C.-H., Malavieille, J., Lu, C.-Y., Tang, J.-T., et al. (2018). Basal Accretion, a Major Mechanism for Mountain Building in Taiwan Revealed in Rock thermal History. J. Asian Earth Sci. 152 (300), 80-90. doi:10.1016/j.jseaes.2017.11.030

Chen, C. T., Chan, Y. C., Beyssac, O., Lu, C. Y., Chen, Y. G., Malavieille, J., et al. (2019). Thermal History of the Northern Taiwanese Slate Belt and Implications for Wedge Growth during the Neogene Arc-Continent Collision. Tectonics 38 (9), 3335-3350. doi:10.1029/2019TC005604

Chen, Y.-W., Shyu, J. B. H., and Chang, C.-P. (2015). Neotectonic Characteristics along the Eastern Flank of the Central Range in the Active Taiwan Orogen Inferred from Fluvial Channel Morphology. Tectonics 34 (10), 2249-2270. doi:10.1002/2014TC003795

Chung, S.-L., Lee, T.-Y., Lo, C.-H., Wang, P.-L., Chen, C.-Y., Yem, N. T., et al. (1997). Intraplate Extension Prior to continental Extrusion along the Ailao Shan-Red River Shear Zone. Geol 25 (4), 311. doi:10.1130/0091-7613(1997) $025<0311$ :ieptce $>2.3 . c 0 ; 2$

Clark, M. K., Schoenbohm, L. M., Royden, L. H., Whipple, K. X., Burchfiel, B. C., Zhang, X., et al. (2004). Surface Uplift, Tectonics, and Erosion of Eastern Tibet from Large-Scale Drainage Patterns. Tectonics 23, a-n. doi:10.1029/ 2002TC001402

Crespi, J. M., Chan, Y.-C., and Swaim, M. S. (1996). Synorogenic Extension and Exhumation of the Taiwan Hinterland. Geol 24 (3), 247-250. doi:10.1130/00917613(1996)024<0247:seaeot>2.3.co;2

Di Naccio, D., Boncio, P., Brozzetti, F., Pazzaglia, F. J., and Lavecchia, G. (2013). Morphotectonic Analysis of the Lunigiana and Garfagnana Grabens (Northern
Constructive and helpful comments from reviewers to improve the manuscript are deeply appreciated. We also thank the Taiwan International Graduate Program and the Institute of Earth Sciences, Academia, Taiwan, for financially supporting the first author's study in the $\mathrm{PhD}$ program. DEM data used in this study is available through the website https:// search.earthdata.nasa.gov/search and https://search.asf.alaska. $\mathrm{edu} / \# /$.

Apennines, Italy): Implications for Active normal Faulting. Geomorphology 201, 293-311. doi:10.1016/j.geomorph.2013.07.003

Dinh, T.-H., Chan, Y.-C., Chang, C.-P., Chen, C.-T., and Hsu, Y.-C. (2020). Deformation Patterns and Potential Active Movements of the Fansipan Mountain Range, Northern Vietnam. Int. J. Earth Sci. (Geol Rundsch) 110, 35-51. doi:10.1007/s00531-020-01931-8

Dung, P. T., Hoa, T. T., Anh, T. T., Hieu, T. V., Ly, V. H., Ching-Ying, L., et al. (2012). New Data of Ye Yen Sun Granite Complex in Phan Si Pan Uplift. VIETNAM JOURNAL EARTH SCIENCES 34 (3), 193-204. doi:10.15625/0866$7187 / 34 / 3 / 2535$

Duong, N. A., Sagiya, T., Kimata, F., To, T. D., Hai, V. Q., Cong, D. C., et al. (2013). Contemporary Horizontal Crustal Movement Estimation for Northwestern Vietnam Inferred from Repeated GPS Measurements. Earth Planet. Sp 65, 1399-1410. doi:10.5047/eps.2013.09.010

Faure, M., Lepvrier, C., Nguyen, V. V., Vu, T. V., Lin, W., and Chen, Z. (2014). The South China Block-Indochina Collision: where, when, and How? J. Asian Earth Sci. 79 (PA), 260-274. doi:10.1016/j.jseaes.2013.09.022

Font, M., Amorese, D., and Lagarde, J.-L. (2010). DEM and GIS Analysis of the Stream Gradient index to Evaluate Effects of Tectonics: The Normandy Intraplate Area (NW France). Geomorphology 119 (3-4), 172-180. doi:10.1016/j.geomorph.2010.03.017

Gaidzik, K., and Ramírez-Herrera, M. T. (2017). Geomorphic Indices and Relative Tectonic Uplift in the Guerrero Sector of the Mexican Forearc. Geosci. Front. 8 (4), 885-902. doi:10.1016/j.gsf.2016.07.006

Giletycz, S., Loget, N., Chang, C.-P., and Mouthereau, F. (2015). Transient Fluvial Landscape and Preservation of Low-Relief Terrains in an Emerging Orogen: Example from Hengchun Peninsula, Taiwan. Geomorphology 231, 169-181. doi:10.1016/J.GEOMORPH.2014.11.026

Hack, J. T. (1973). Stream-profile Analysis and Stream-Gradient index. J. Res. Us Geol. Surv. 1 (4), 421-429.

Hooke, R. L. (2003). Time Constant for Equilibration of Erosion with Tectonic Uplift. Geol 31, 621-624. doi:10.1130/0091-7613(2003)031<0621:tcfeoe>2.0.c0;2

Kirby, E., and Ouimet, W. (2011). Tectonic Geomorphology along the Eastern Margin of Tibet: Insights into the Pattern and Processes of Active Deformation Adjacent to the Sichuan Basin. Geol. Soc. Lond. Spec. Publications 353 (1), 165-188. doi:10.1144/SP353.9

Kirby, E., Whipple, K. X., Burchfiel, B. C., Tang, W., Berger, G., Sun, Z., et al. (2000). Neotectonics of the Min Shan, China: Implications for Mechanisms Driving Quaternary Deformation along the Eastern Margin of the Tibetan Plateau. Geol. Soc. America Bull. 112 (3), 375-393. doi:10.1130/00167606(2000)112<375:notmsc >2.0.co;2

Kirby, E., and Whipple, K. X. (2012). Expression of Active Tectonics in Erosional Landscapes. J. Struct. Geology. 44, 54-75. doi:10.1016/J.JSG.2012.07.009

Lai, K.-Y., Chen, Y.-G., and Lâm, D. Đ. (2012). Pliocene-to-present Morphotectonics of the Dien Bien Phu Fault in Northwest Vietnam. Geomorphology 173-174, 52-68. doi:10.1016/j.geomorph.2012.05.026

Lan, C.-Y., Chung, S.-L., Lo, C.-H., Lee, T.-Y., Wang, P.-L., Li, H., et al. (2001). First Evidence for Archean continental Crust in Northern Vietnam and its Implications for Crustal and Tectonic Evolution in Southeast Asia. Geol 29 (3), 219. doi:10.1130/0091-7613(2001)029<0219:fefacc $>2.0$. co;2

Leeder, M. R., and Jackson, J. A. (1993). The Interaction Between Normal Faulting and Drainage in Active Extensional Basins, With Examples From the Western United States and Central Greece. Basin Res. 5, 79-102. doi:10.1111/j.13652117.1993.tb00059.x

Leloup, P. H., Lacassin, R., Tapponnier, P., Schärer, U., Zhong, D., Liu, X., et al. (1995). The Ailao Shan-Red River Shear Zone (Yunnan, China), Tertiary 
Transform Boundary of Indochina. Tectonophysics 251 (1-4), 3-84. doi:10.1016/0040-1951(95)00070-4

Leloup, P. H., Arnaud, N., Lacassin, R., Kienast, J. R., Harrison, T. M., Trong, T. T. P., et al. (2001). New Constraints on the Structure, Thermochronology, and Timing of the Ailao Shan-Red River Shear Zone, SE Asia. J. Geophys. Res. 106 (B4), 6683-6732. doi:10.1029/2000JB900322

Merritts, D., and Vincent, K. R. (1989). Geomorphic Response of Coastal Streams to Low, Intermediate, and High Rates of Uplift, Medocino Triple junction Region, Northern California. Geol. Soc. America Bull. 101 (11), 1373-1388. doi:10.1130/0016-7606(1989)101<1373:grocst>2.3.co;2

Molnar, P., and Tapponnier, P. (1975). Cenozoic Tectonics of Asia: Effects of a Continental Collision: Features of Recent continental Tectonics in Asia Can Be Interpreted as Results of the India-Eurasia Collision. Science 189, 419-426. Available at: https://www.jstor.org/stable/pdf/1740465.pdf?refreqid=excelsior \%3A31f05b36d77acb7e417f539clef8f202. doi:10.1126/science.189.4201.419

Nam, T. N. (2001). Ages of the Ca Vinh and Xom Giau Complexes: First Reliable Evidence from SHRIMP U-Pb Zircon Dating. Geol. Ser. A 262, 1-11.

Nguyen, V.-D., Huang, B.-S., Le, T.-S., Dinh, V.-T., Zhu, L., and Wen, K.-L. (2013). Constraints on the Crustal Structure of Northern Vietnam Based on Analysis of Teleseismic Converted Waves. Tectonophysics 601, 87-97. doi:10.1016/ J.TECTO.2013.04.031

Osmundsen, P. T., Henderson, I., Lauknes, T. R., Larsen, Y., Redfield, T. F., and Dehls, J. (2009). Active normal Fault Control on Landscape and Rock-Slope Failure in Northern Norway. Geology 37 (2), 135-138. doi:10.1130/G25208A.1

Phan, D. P., Tokarski, A. K., Świerczewska, A., Strzelecki, P. J., Waliczek, M., Krąpiec, M., et al. (2019). Neotectonic (Miocene to Recent) Vertical Movements in the Lao Cai Basin (Red River Fault Zone, Vietnam): An Approach to Seismic hazard Assessment. J. Asian Earth Sci. 181 (December 2018), 103885. doi:10.1016/j.jseaes.2019.103885

Phan, V., Ngo-Duc, T., and Ho, T. (2009). Seasonal and Interannual Variations of Surface Climate Elements over Vietnam. Clim. Res. 40 (1), 49-60. doi:10.3354/ cr00824

Replumaz, A., Lacassin, R., Tapponnier, P., and Leloup, P. H. (2001). Large River Offsets and Plio-Quaternary Dextral Slip Rate on the Red River Fault (Yunnan, China). J. Geophys. Res. 106, 819-836. doi:10.1029/2000jb900135

Royden, L. H., Burchfiel, B. C., King, R. W., Wang, E., Chen, Z., Shen, F., et al. (1997). Surface Deformation and Lower Crustal Flow in Eastern Tibet. Science 276 (5313), 788-790. doi:10.1126/science.276.5313.788

Schärer, U., Tapponnier, P., Lacassin, R., Leloup, P. H., Zhong, D., and Shaocheng, J. (1990). Intraplate Tectonics in Asia: A Precise Age for Large-Scale Miocene Movement along the Ailao Shan-Red River Shear Zone, China. Earth Planet. Sci. Lett. 97 (1-2), 65-77. doi:10.1016/0012-821X(90)90099-J

Schoenbohm, L. M., Whipple, K. X., Burchfiel, B. C., and Chen, L. (2004). Geomorphic Constraints on Surface Uplift, Exhumation, and Plateau Growth in the Red River Region, Yunnan Province, China. Geol. Soc. America Bull. 116 (7-8), 895-909. doi:10.1130/B25364.1

Schreurs, G. (1994). Experiments on Strike-Slip Faulting and Block Rotation. Geol 22, 567-570. doi:10.1130/0091-7613(1994)022<0567:eossfa>2.3.co;2

Searle, M. P., Yeh, M.-W., Lin, T.-H., and Chung, S.-L. (2010). Structural Constraints on the Timing of Left-Lateral Shear along the Red River Shear Zone in the Ailao Shan and Diancang Shan Ranges, Yunnan, SW China. Geosphere 6 (4), 316-338. doi:10.1130/GES00580.1

Shellnutt, J. G., Pham, T. T., Denyszyn, S. W., Yeh, M.-W., and Tran, T.-A. (2020). Magmatic Duration of the Emeishan Large Igneous Province: Insight from Northern Vietnam. Geology 48 (5), 457-461. doi:10.1130/G47076.1

Shen, Z.-K., Lü, J., Wang, M., and Bürgmann, R. (2005). Contemporary Crustal Deformation Around the Southeast Borderland of the Tibetan Plateau. J. Geophys. Res. 110 (B11). doi:10.1029/2004JB003421

Stephenson, R., and Lambeck, K. (1985). Erosion-Isostatic Rebound Models for Uplift: An Application to South-Eastern Australia. Geophys. J. R. Astron. Soc. 82, 31-55. doi:10.1111/j.1365-246X.1985.tb05127.x

Stern, T. A., Baxter, A. K., and Barrett, P. J. (2005). Isostatic Rebound Due to Glacial Erosion within the Transantarctic Mountains. Geol 33 (3), 221-224. doi:10.1130/G21068.1

Stewart, I. S., and Hancock, P. L. (1990). What Is Fault Scarp? Episodes 13, 256-263. Tapponnier, P., Lacassin, R., Leloup, P. H., Schärer, U., Dalai, Z., Haiwei, W., et al. (1990). The Ailao Shan/Red River Metamorphic belt: Tertiary Left-Lateral
Shear between Indochina and South China. Nature 343 (6257), 431-437. doi:10.1038/343431a0

Tapponnier, P., Peltzer, G., Le Dain, A. Y., Armijo, R., and Cobbold, P. (1982). Propagating Extrusion Tectonics in Asia: New Insights from Simple Experiments with Plasticine. Geol 10 (12), 611-616. doi:10.1130/00917613(1982)10<611:petian>2.0.co;2

Tapponnier, P., Zhiqin, X., Roger, F., Meyer, B., Arnaud, N., Wittlinger, G., et al. (2001). Oblique Stepwise Rise and Growth of the Tibet Plateau. Science 294 (5547), 1671-1677. doi:10.1126/science.105978

Trần, Đ. T., Nguyễn, T. Y., Dương, C. C., Vy, Q. H., Zuchiewicz, W., Nguyễnng, Q. C. ò. n., et al. (2013). Recent Crustal Movements of Northern Vietnam from GPS Data. J. Geodynamics 69, 5-10. doi:10.1016/j.jog.2012.02.009

Tran, T. H., Lan, C.-Y., Usuki, T., Shellnutt, J. G., Pham, T. D., Tran, T. A., et al. (2015). Petrogenesis of Late Permian Silicic Rocks of Tu Le basin and Phan Si Pan Uplift (NW Vietnam) and Their Association with the Emeishan Large Igneous Province. J. Asian Earth Sci. 109, 1-19. doi:10.1016/J.JSEAES.2015.05.009

Troiani, F., and Della Seta, M. (2008). The Use of the Stream Length-Gradient index in Morphotectonic Analysis of Small Catchments: A Case Study from Central Italy. Geomorphology 102 (1), 159-168. doi:10.1016/ j.geomorph.2007.06.020

Usuki, T., Lan, C.-Y., Tran, T. H., Pham, T. D., Wang, K.-L., Shellnutt, G. J., et al. (2015). Zircon U-Pb Ages and Hf Isotopic Compositions of Alkaline Silicic Magmatic Rocks in the Phan Si Pan-Tu Le Region, Northern Vietnam: Identification of a Displaced Western Extension of the Emeishan Large Igneous Province. J. Asian Earth Sci. 97, 102-124. doi:10.1016/J.JSEAES.2014.10.016

Wang, K. (2020). Mountain Height Might Be Controlled by Tectonic Force, rather Than Erosion. Nature 582 (7811), 189-190. doi:10.1038/d41586-020-01601-4

Wang, Y., Schoenbohm, L. M., Zhang, B., Granger, D. E., Zhou, R., Zhang, J., et al. (2017). Late Cenozoic Landscape Evolution along the Ailao Shan Shear Zone, SE Tibetan Plateau: Evidence from Fluvial Longitudinal Profiles and Cosmogenic Erosion Rates. Earth Planet. Sci. Lett. 472, 323-333. doi:10.1016/j.epsl.2017.05.030

Wang, Y., Zhang, B., Schoenbohm, L. M., Zhang, J., Zhou, R., Hou, J., et al. (2016). Late Cenozoic Tectonic Evolution of the Ailao Shan-Red River Fault (SE Tibet): Implications for Kinematic Change during Plateau Growth. Tectonics 35 (8), 1969-1988. doi:10.1002/2016TC004229

Whipple, K. X. (2004). BEDROCK RIVERS AND THE GEOMORPHOLOGY OF ACTIVE OROGENS. Annu. Rev. Earth Planet. Sci. 32 (1), 151-185. doi:10.1146/annurev.earth.32.101802.120356

Wobus, C., Whipple, K. X., Kirby, E., Snyder, N., Johnson, J., Spyropolou, K., et al. (2006). "Tectonics from Topography: Procedures, Promise, and Pitfalls," in Special Paper 398: Tectonics, Climate, and Landscape Evolution (Geological Society of America), 55-74. doi:10.1130/2006.2398(04)

Yeh, M.-W., Wintsch, R. P., Liu, Y.-C., Lo, C.-H., Chung, S.-L., Lin, Y.-L., et al. (2014). Evidence for Cool Extrusion of the North Indochina Block along the Ailao Shan Red River Shear Zone, a Diancang Shan Perspective. J. Geology. 122 (5), 567-590. doi:10.1086/677263

Zhang, R. Y., Lo, C.-H., Chung, S.-L., Grove, M., Omori, S., Iizuka, Y., et al. (2013). Origin and Tectonic Implication of Ophiolite and Eclogite in the Song Ma Suture Zone between the South China and Indochina Blocks. J. Metamorphic Geology. 31 (1), 49-62. doi:10.1111/jmg.12012

Conflict of Interest: The authors declare that the research was conducted in the absence of any commercial or financial relationships that could be construed as a potential conflict of interest.

Publisher's Note: All claims expressed in this article are solely those of the authors and do not necessarily represent those of their affiliated organizations, or those of the publisher, the editors, and the reviewers. Any product that may be evaluated in this article, or claim that may be made by its manufacturer, is not guaranteed or endorsed by the publisher.

Copyright $\odot 2022$ Dinh, Chan and Chen. This is an open-access article distributed under the terms of the Creative Commons Attribution License (CC BY). The use, distribution or reproduction in other forums is permitted, provided the original author(s) and the copyright owner(s) are credited and that the original publication in this journal is cited, in accordance with accepted academic practice. No use, distribution or reproduction is permitted which does not comply with these terms. 